ARID International Journal of Social Sciences and Humanities (AIJSSH) VOL.2, NO.4, July 2020

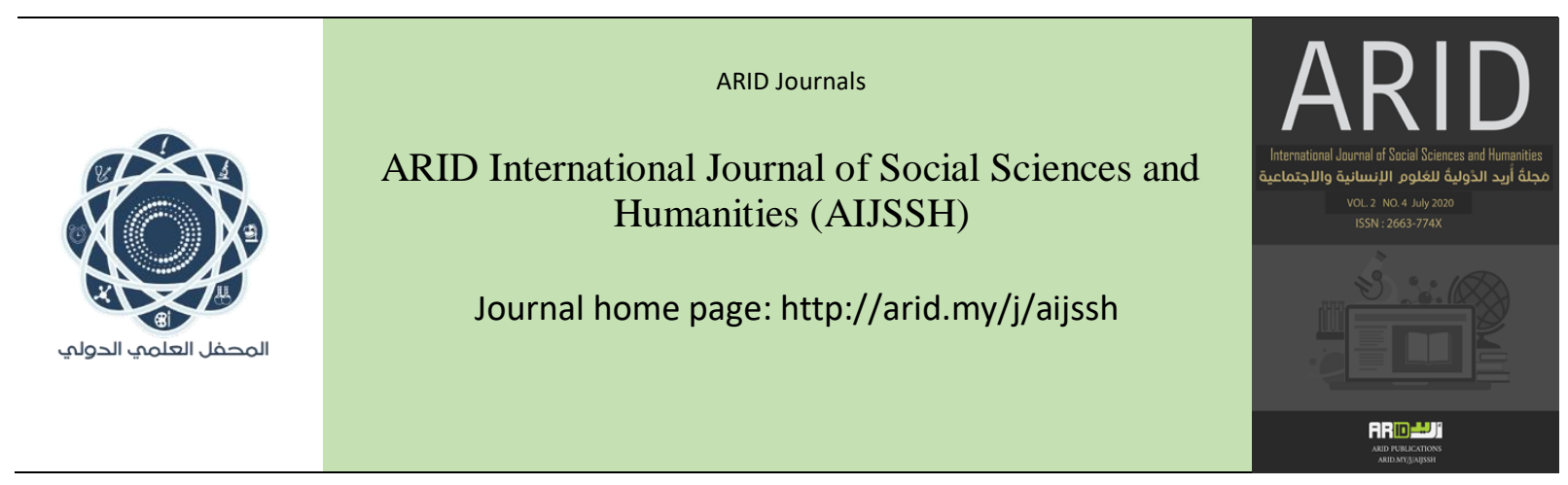

$$
\text { مَجلةُ أُريد الدَّوليةُ للعُلورج الإنسانية والإجتماعية }
$$

\title{
Slang and its impact on the Arabic tongue
}

Dr.Zain Alabeden Hajeb Mohammd Adnan Alattar* Jehad Mohamad ALHennawy

$$
\text { زين العابدية وأثر ها على اللّسان العربي }
$$$$
\text { atarmohda@gmail.com }
$$$$
\text { arid.my/0004-0325 }
$$ 


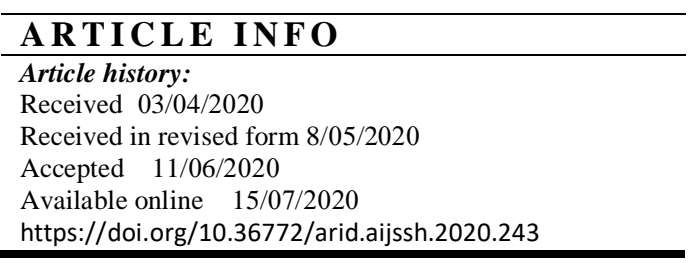

\begin{abstract}
Vernacular dialects appeared strongly when Arabs mixed with others, during the Islamic conquests in the early days of Islam, and with the passage of time and Arabs mixed with others, and because hearing is the father of the linguistic queens, and due to time people gradually drifted away from classical, especially in the language of daily conversation. In the modern era, calls for the rejection of al-Fusha and the use of vernacular by Western orientalists and their Arab recruits, who carried the banner of antagonism under brilliant names such as: facilitation, reform, and the study of dialects, and others, escalated, and the vernacular prevailed over the daily conversation of people, and was counterbalanced by the actual deterioration of the classical, This has resulted in many dangers, including: that colloquies cut off the present of Arabs from their past; Because future generations will not understand the heritage of their ancestors, and illiteracy has also worked to fragment and disintegrate the Arab nation, and Arab colloquials have become dictionaries to clarify their meanings, and ... therefore, it was necessary for Arabism to remain the strongest bond that unites Arab peoples, so decision-makers must From practical steps to reduce colloquials, by reviewing the educational and educational curricula so that they are disposed to achieve proper reading, writing and conversation, from kindergarten to graduation, so that linguistic security becomes an integral part of cultural security, and media and social media must be adapted to carry the language Classical, and above all the education of the child and the Arab individual on the sense of the value of classical language, it reflects the sovereignty of the nation speaking it.
\end{abstract}




\section{المُلَّْص}

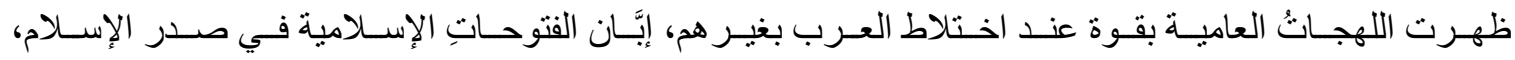

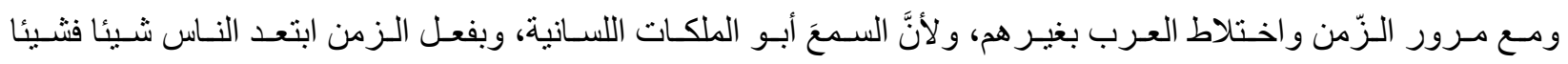
عـن الفصـحى، لا سـيَّما في لغــة الحـديث اليـومي. وفـي العصـر الحـديث تصــاعدت الـــعواتُ إلـى نبـذِ الفصـحى واسـتخدام

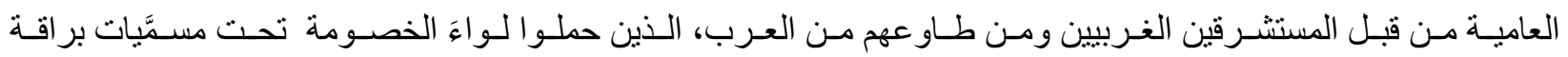
مثـل: التيسـير، و الإصـلاح، ودر اسـة اللهجـات، و غير هـا، فأصـبحت العاميـةُة تطغسى على الحـديث اليـومي للنـاس، ويقابلـهـ

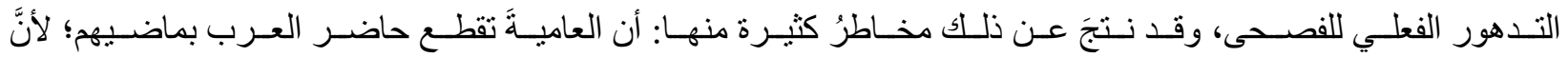

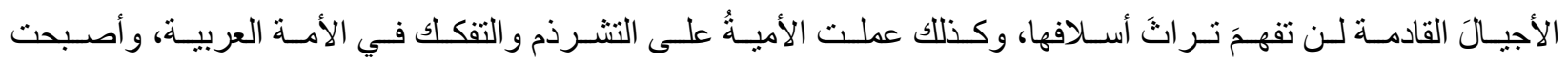

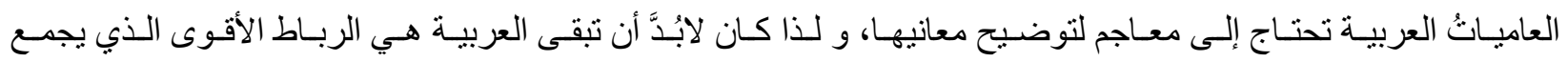
الثــوب العربيـة، فكـان لا بـدَّ لأصـحاب القرار مـن خطـوات عمليـة للحدِّ مـن العاميـات، وذللك بإعـادة النظـر في المنـاهج

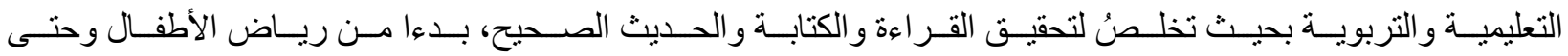

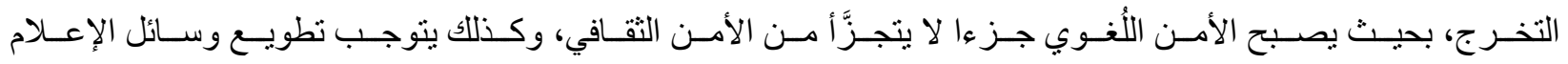
ووسـائل التو اصـل الاجتمـاعي لحمـل اللغــة الفصـحى، وقبـل هـذا كلـهـ تربيـة الطفـل و الفـرد العربـي على الثـعورِ بقيمـة اللغة الفصحى، فهي تعبِّر عن سيادة الأمة الناطقة بها. 
المقِّمة:

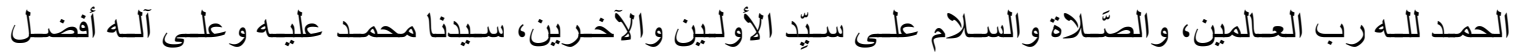
الصلاة و أنمّ التسليم، وبعد:

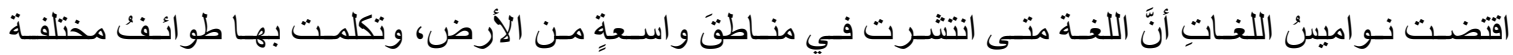

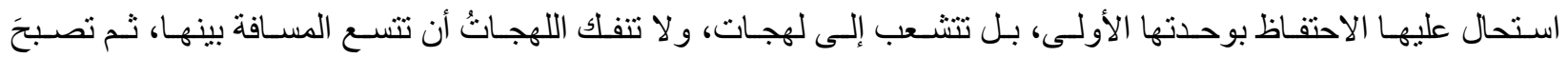

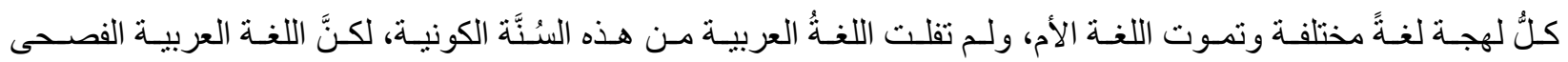

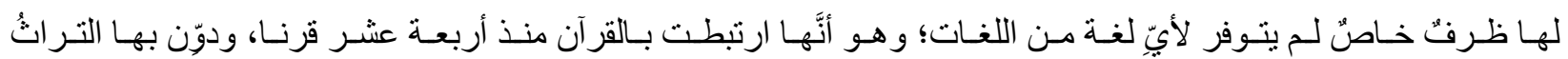
الضخم الذي كان القرآن محوره.

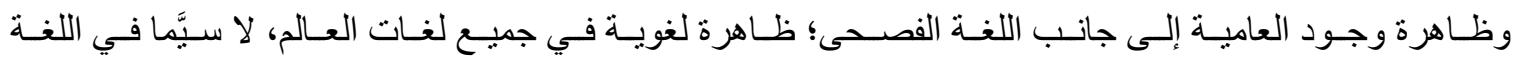
العربيـة، والتـي حافظت على قوتهـا وفصـاحتها على مـرِّ القرون، لكن سـر عان مـا بـدأت العاميـة تنتشـر شـيئا فثـيئا بـين

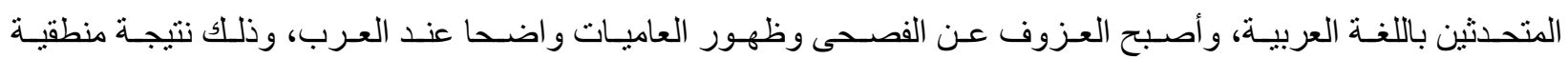
لتمزق الأمة وتشرذمها في عصور انحطاطها. لـذا يسـعى هـا البحــث إلـى الوقـوف على ظـاهرة تـؤثر سـلبا على اللسـان العربـي؛ وهـي ظـاهرة غلبـة العاميـة

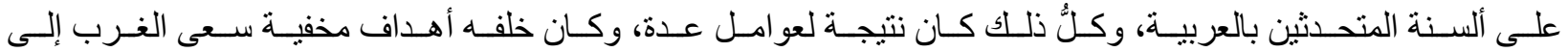
تحقيقهـا مـن أجـل محاربـة الإسـلام، و لا أدلَّ علـى ذلـك مـن قـول (ولـيم جيفـور دبلجـراف): "متـى تـوارى القـرآن ومدينــة مكة عن العرب، يمكننا حينئذ أن نرى العربي يتدرج في سبيل الحضارة التي لم يبعده عنها إلا محمد وكتابه". ويتتـاول هـذا البحـث أثثر العاميـة على اللسـان العربـي، حيث تـــــل تعريـف العاميـة ومبادئهـا، وكـذلك تعريـف اللغــة الفصــى و عناصـر ها وأهميتهـا، ثـم تعـرَّض البحـث للـدعوات الهدامـة لاســتخدام العاميـة، حيـث ذكـر البحـث أبـرز

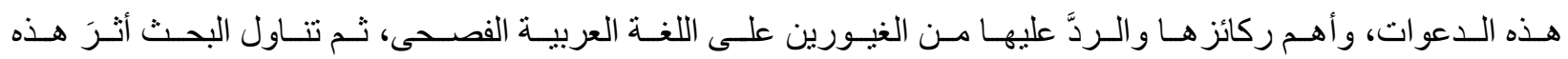

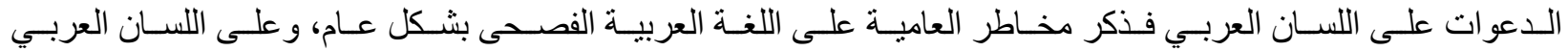
بشـكل خـاص، ثم ذكـر البحـث أسـباب تـدهور الفصـحى، ومـن ثـم عـرض كيفــة الحفـاظ على اللســان العربـي مـن غـزو العاميات، وسبل التصدي لهذه المشكلة. 
وقد اسـتخدم الباحـث المـنهج الوصـفي التحليلـي الـذي يناسـب مثنل هـذه الدراسـات اللغويـة؛ فهـو يحلاهـا تحلـيلا و اقعيا بحيث يمكننا الوصول لأفضل النتائج المرجوَّة.

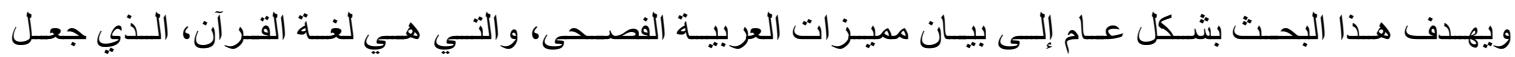
العربيـة مميـزة عـن غيرهـا مـن اللغــات العالميـة التـي انــثرت بفعـل الزمسان، وكـذلك مـن حيـث اسـتيعابها للعقل العربـي،

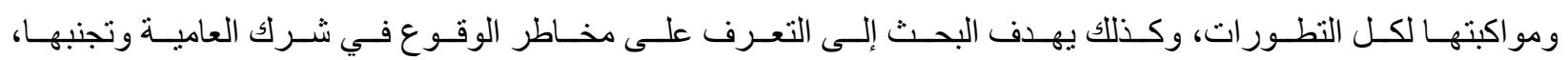
ويهـدف إلـى توعيـة أبنـاء العربيـة بخطـر إهمـالهم للغــة الفصـحى ومـيلهم إلـى التســاهل في التعامـل مـع العاميـات، ومـالـهـ من أثر خطير على اللسان العربي.

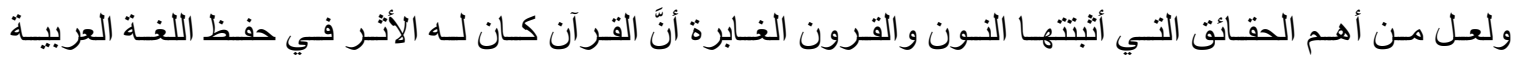

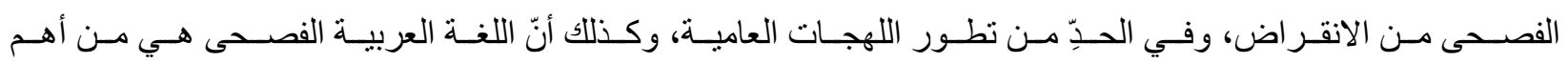

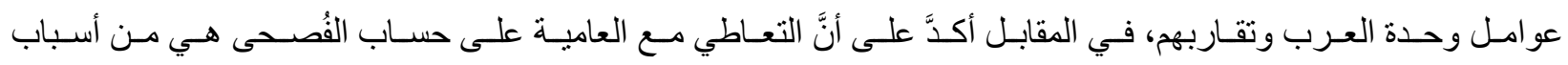

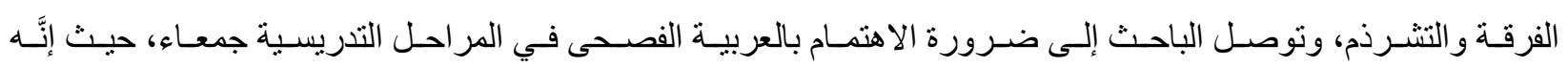

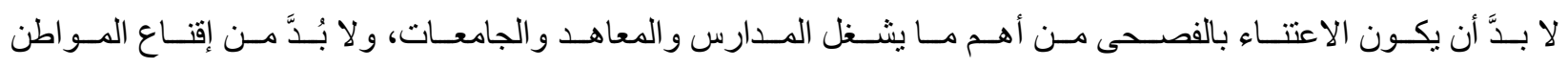
العربي أنَّ اللغة الفصحى خيرُ و عاء يجمع العرب بعد الإسلام.

\section{المبحث الأول: بين الفصحى والعامية}

\section{المطلب الأول: اللغة العامية نشأتها ومفهومها}

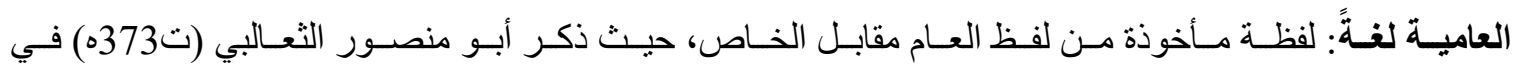
معجمه تهذيب اللغة: "يُقال رجلّ عُمى، ورجل قُصري، فالعمى العام، والقصري الخاص".[1]

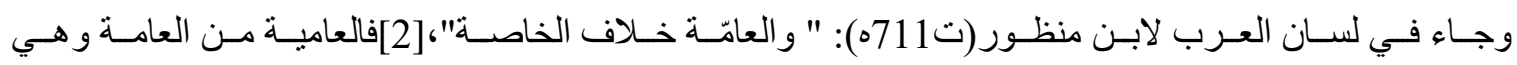
خلاف الخاصنة، ويُقال للمذكَّر عاميّ عند نسبته، ويُقال للمؤنث عامية عند نسبتها، لذا يُقال اللُّة العامية.

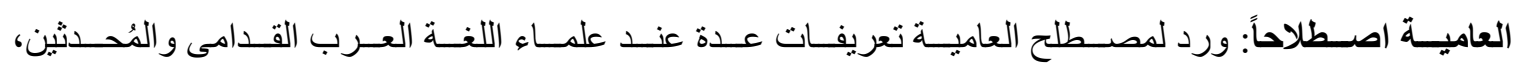

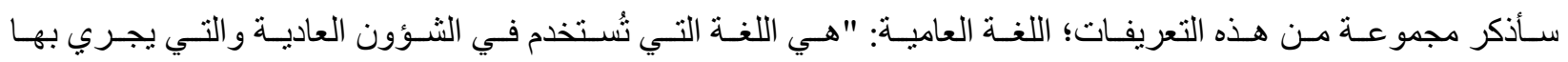

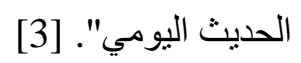




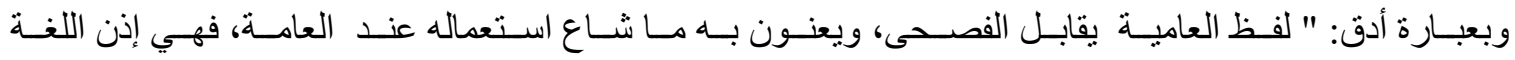

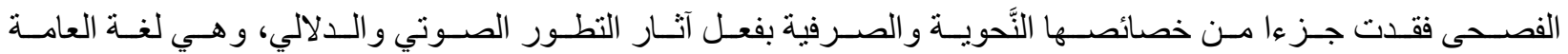

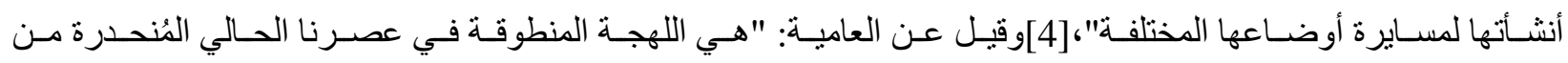

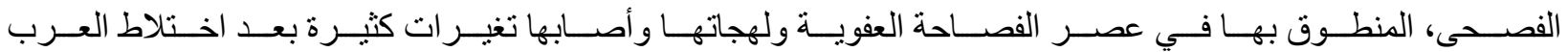
[5غير هم..." [5

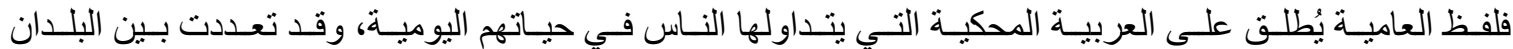
العربية، و إن شُتَ فقل تعددت داخل البلد الواحد. وقـد تبـاين العلمـاء فـي فهمهم لمصـطلح العاميـة؛ فــنهم مـن ير اهـا لغـة قائمسة بـذاتها، و هنـالك مـن ير اهـا مـأخوذة عن الفصحى أو مرتبطة بها، ولكل منهم رأيه.

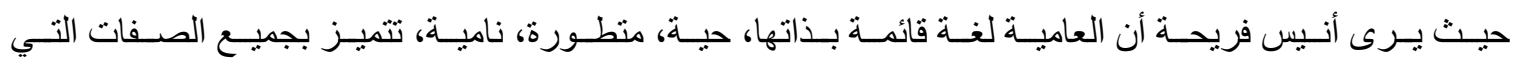

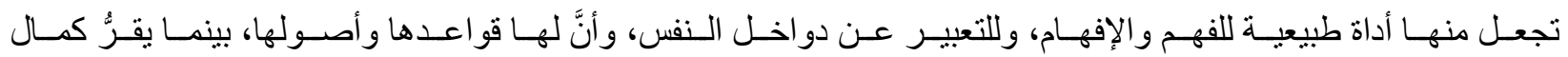
يوسـف الحساج بـأنَّ العاميـة مـأخوذة عـن الفصـحى ومرتبطــة بهـا، أمَّـا الــكتور كمـال بِشـر فيـرى أنَّ العاميـة لغـات غيـر نامية بينما اللهجة هي التنوع ذو القرابة بالأصل و المُتولِّد عن أصل عام. [6]

\section{المطلبُ الثاني: عوامل ظهور العامية}

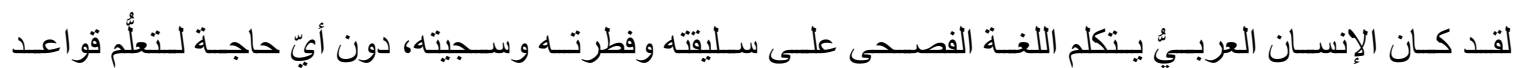

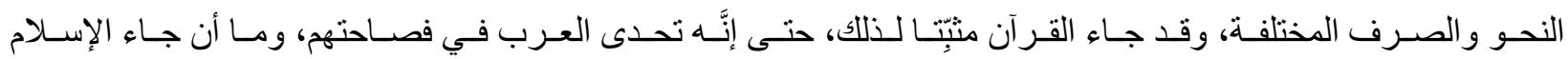

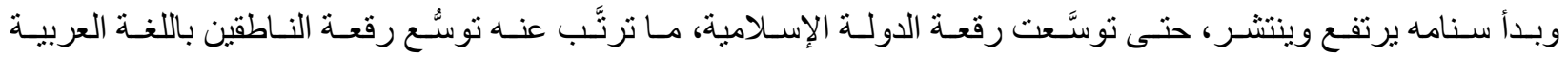

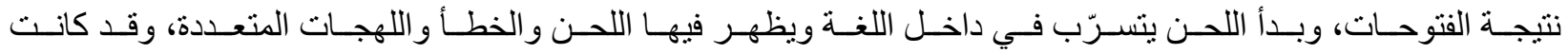

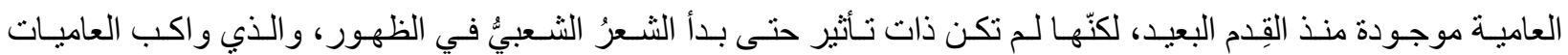

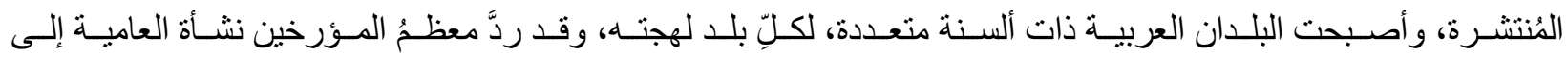
خروج اللغة العربية من موطنها الأصلي، و احتكاكها باللغات الأخرى.

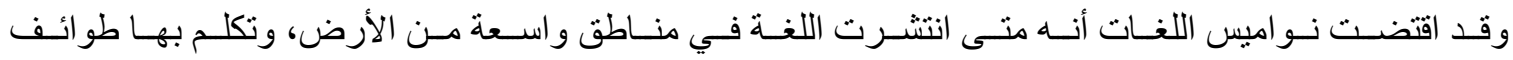

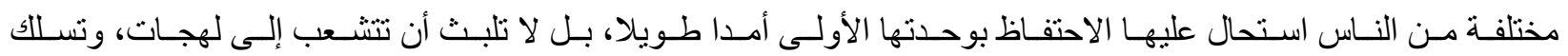


كل لهجـة طريقهـا، ولا تنفلك تتسـع المسـافة بينها حتـى تصـبح كل لهجـة منهـا منميزة غيـر مفهومـة إلا عند أهلهـا، ولهذا القـانون خضـعت اللغــات الإنسـانية على مـرِّ العصـور، ولـم تفلـت العربيـة مـن هـذا المصـير، فمنـذ أن اتسـع انتشــار ها بسـبب الفتوحسات الإسـلامية وانتشـار الإسـلام في الأمصـار المتعـددة أخـذت تتشـعب إلـى لهجـات، وأخـذت المسـافة تتسـع بين هذه اللهجات حتى أصبح بعضها غريبا؛ فلهجة العراق في العصر الحالي لا يفهمها المصري، وهكذا...[7] وقد أجمل الدكتور عبده الراجحي عوامل نشأة العامية كالآتي:

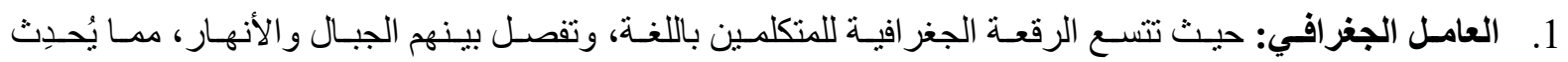

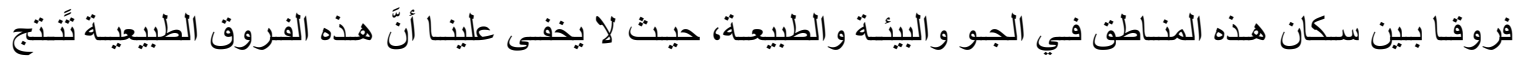
فروقا لغوبة؛ فالذين يعيشون في القُرى يتكلمون لغة غير التي يتكلمها الذين يعيشون في المُدن.

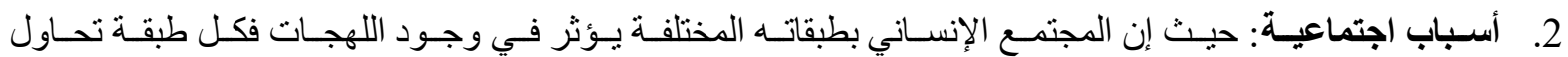

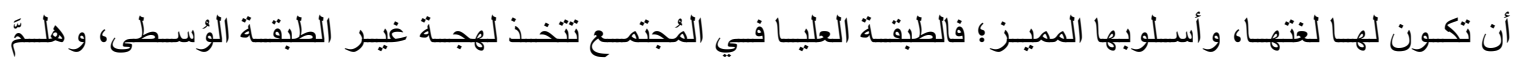
جرَّا. و وسن الأسـباب الاجتماعيـة احتكـالك اللغــات واختلاطهـا نتيجـة غـزو أو هجـرات، وهـذا الاحتكـاك أو الصـراع اللغـوي يعـدُ مـن أهـم الأسـباب التـي تـؤدي إلـى نشـأة اللهجـات؛ حيـث إنَّ شـعبا يغـزو شـعبا يتكلم لغـة أخـرى؛ فيقوم صـراع

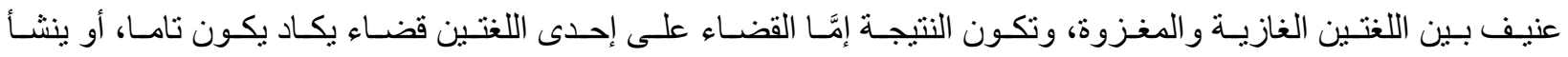
من الصراع لغة مشتقة من اللغتين.

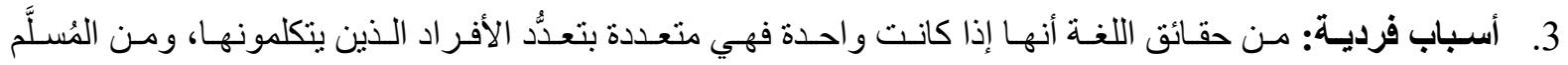

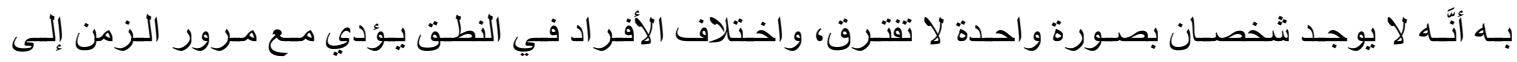
تطوير اللهجة، أو إنشاء لهجات أُخرى.

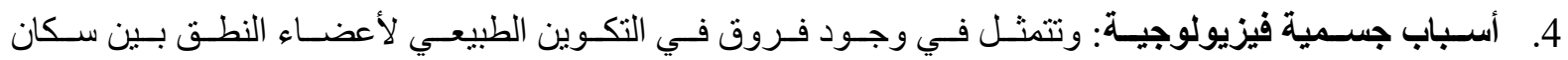
المناطق المختلفة. [8]

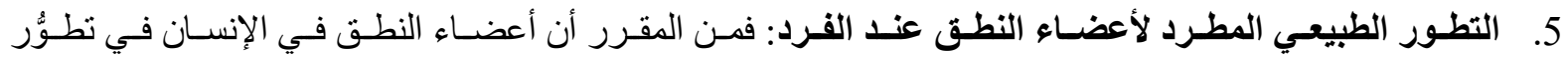
طبيعـي مطـرد فـي بنيتهـا واسـتعدادها ومـنهج أداتهـا ووظائفهـا، فحناجرنــا وحبالنـا الصــوتية و ألسـنتنـا تختلـف 


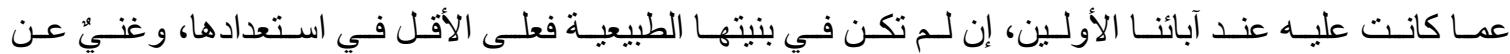
البيان أنّ كل تطوُر في أعضاء النطق ينتجه تطور في أصوات الكلمات.

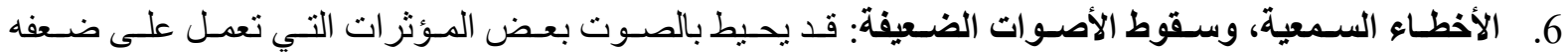

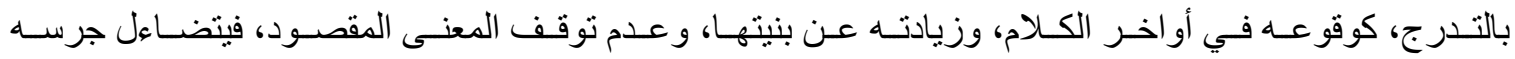

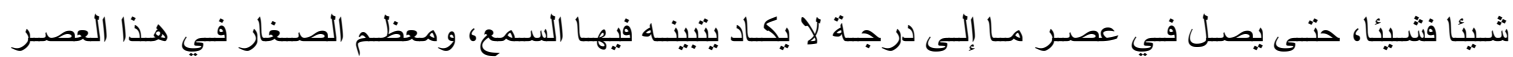
لا يكادون بتنبينونه في نطق الكبار فينطقون بالكلمات مجردة منه.

7. الثـين و الجـيم، ينطـق بهـا فـي عاميـة القـر اء فـي لفظظ (عربنجـي) و هـو سـائق العربـة، فمـن المحتمـل أن يكـون هذا الصوت انتقل إليها من التركية. [9]

\section{المطلب الثالث: التسلسل الزمني لظهور العامية:}

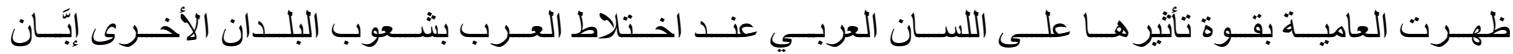

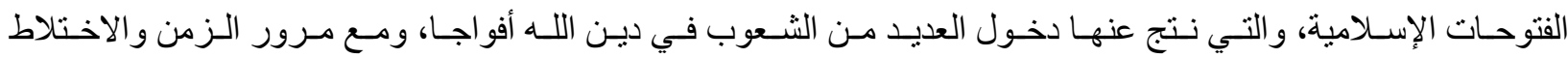

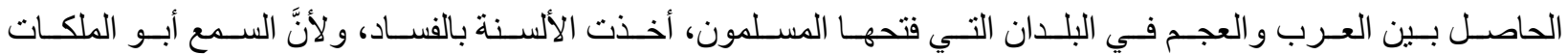

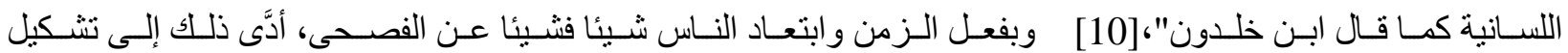

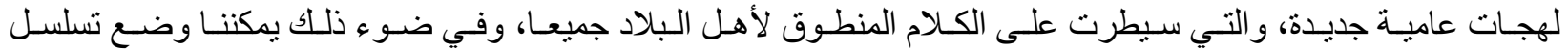
زمني تقديري لظهور العامية:

1. فسـدت الألسـن فـي العصـر العباسـي، وشــاع اللــن بسـبب الاخـتلاط مـع شـعوب الـبلاد المفتوحـة، فظهـرت العامية في بعض الكتابات لكنَّها لم تكن ظاهرة.

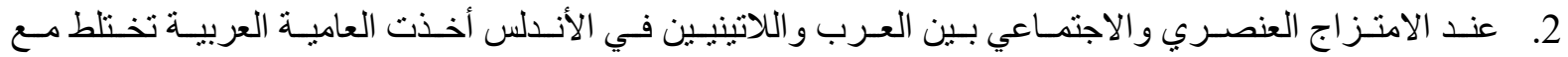

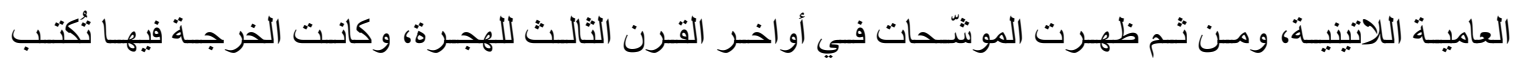
بالعامية في البداية، ثم ما لبثت أن تحوّلت الموشحات في معظمها إلى العامية. 


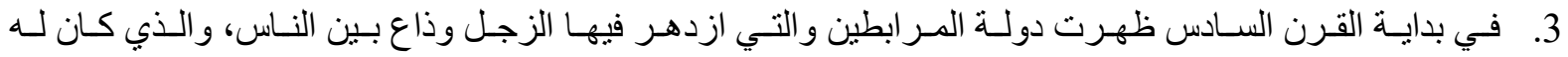
دورٌ سـلبيٌ فـي تكـريس العاميـة، وظهـر فـي المشـرق العربـي الثـعر العـامي، حيـث كـانوا ينظمـون الثـعر العاميّ، وأصبح تذوقُ الشعر الفصيح للفئات المنقفة فقط.

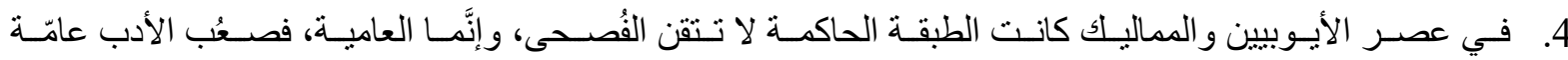
والشعر خاصة، وأصبحت العاميةُ تنتشر بين الناس بسبب عدم إتقانهم للفصحى وليس السبب منهجيا.

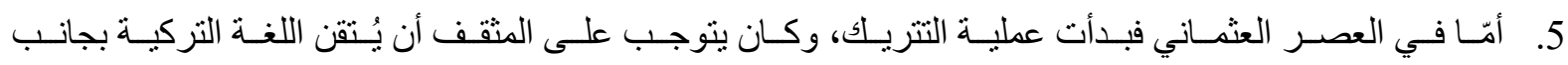
العربيـة، وأخــت الفصـحى فـي الاضـــحلال، وكـان إدخـال المفـردات التركيـة في الحـديث اليـومي بـين النـاس الأثر البالغ في إضعاف اللغة العربية. 6. تم جـاءت مرحلـة الاسـتعمار الأوروبـي للـدول العربيـة، وبـدأت عمليـة فـرض اللُغـات الأوروبيـة على العـرب،

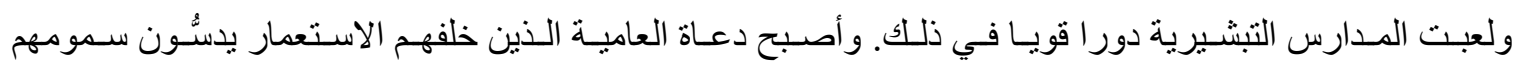
في اللغة، تحت مسمّيات مختلفة والهدف واحد؛ كإصلاح اللغة، أو التطوير، أو التسهيل، أو التجديد. 7. في أيامنـا هذه لجـأ كثثر مـن الكتـاب لاسـتخدام الألفـاظ العاميـة في الأدب بحجـة الواقعيـة، وتحت حجـج أخـرى، فتكرّست العامية وغزت مناحي الحياة كافة. [11]

\section{المطلب الرابع: اللفة الفصحى وأثرها}

- الفصـحى لغـة: الفصـاحة فـي لســان العـرب: " فصـح، الفصـاحة البيـان، وتقـول رجـل فصـيح، وغـلام فصـيح؛

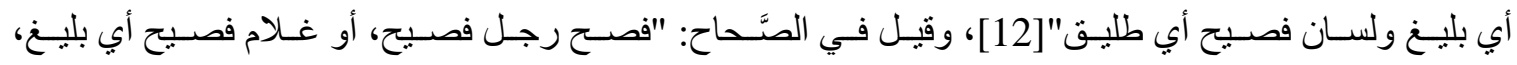

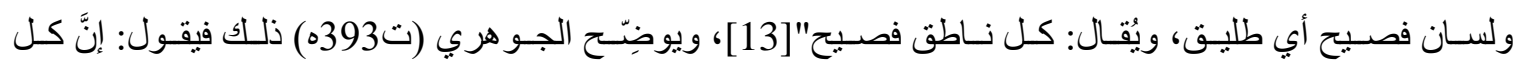

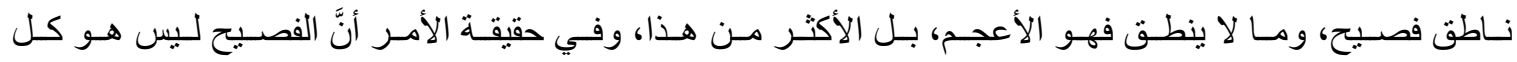

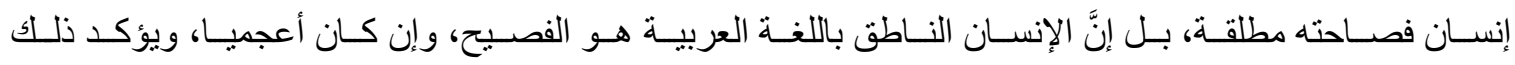

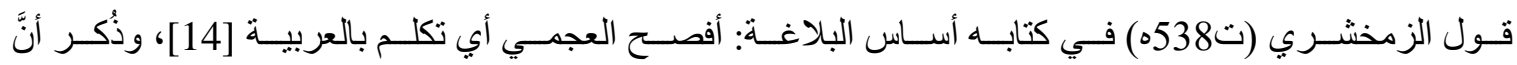
مفهوم الفصـاحة فـي اللغــة هـو الإظهـار، وفـي ذلـك يقـول أبـو هـلال العسـكري (ت395ه): و الثــاهد على أنهـا

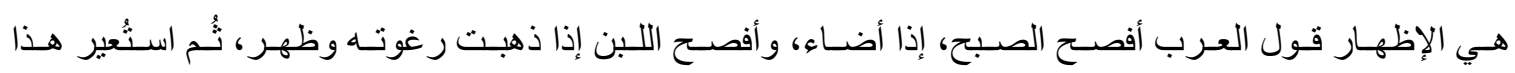




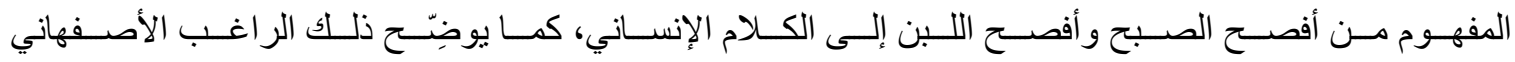
(ت502ه): ومنه استُعبر فصح الرجل جادت لغته". [15] فالإفصاح في اللغة هو الإظهار و الإبانة.

- - الفصـحى اصـطلاحا: يعـرّف أبـو نصـر الفـار ابي (ت339ه) الفصـحى بثـكل عـام قـائلا: فينشـــأ مـن نشـأ على

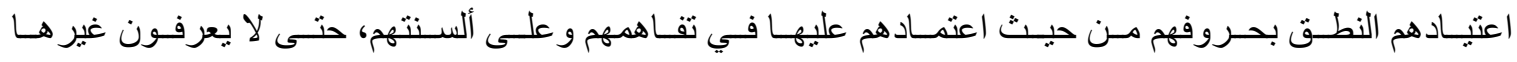

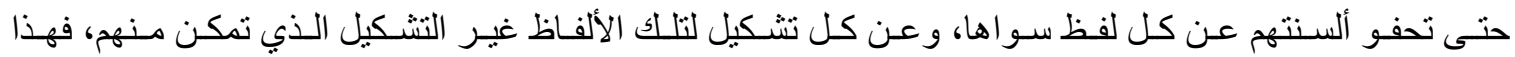

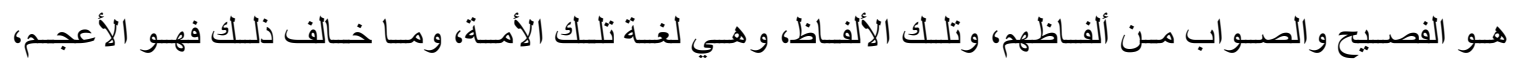
و الخطــأ مـن ألفـاظهم[16]، وقيـل: "الفصـاحة: هـي طلاقـة اللســان أي الخلـوص مـن عقدة اللســان، ويؤكـد ذلـك

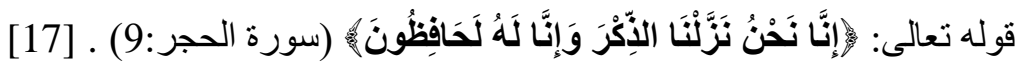
كمــا عرَّفهـا آخـرون؛ الفصـاحة أول لغــة اسـتخدمها العـرب فـي حيـاتهم، وعُرفـت بهـم، وعُرفـوا بهـا، إنهـا اللغــة التي نزل بها القرآن، وسعت كلَّ أحكامه وقو انينه و علومه، إنها لغة العقيدة والدين الإسلامي. [18] ويؤكـــــــه الفكـرة ابـن وهـب (ت335ه) حيـث قـال: إنَّ الفصـيح مـن الكـلام هـو الـذي و وافـق لغـة العـرب...

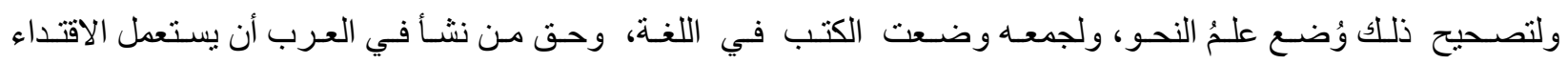
بلغتهم، ولا يخرج عن جهة ألفاظهم، و لا يقتنع في نفسه بمخالفتهم فيخطئوه ويُلحنوه. [19]

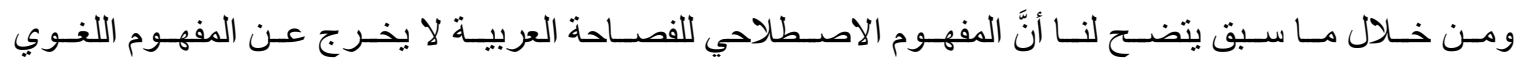
الأصلي السابق، فهو منبثق منه و عليه دون خطأ أو عجمة و عدم وضوح و إبانة وإظهار عن التبليغ. [20] ونستشف من ذلك أنَّ الفصاحة تكمن في استطاعة الفرد التعبير عن كل شيء بكل بساطة ووضوح.

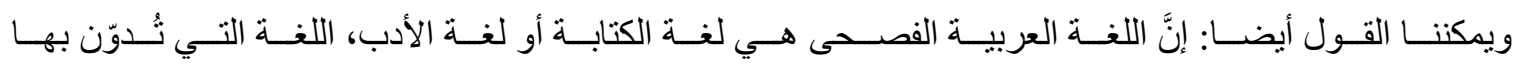

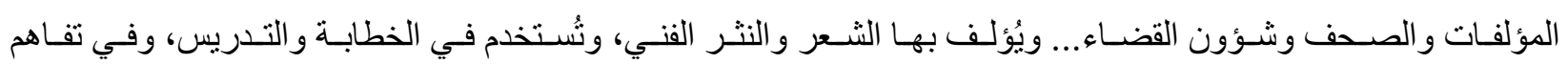
بعضهم مع بعض، فهي لغة القرآن الكريم، والتراث العربي و التي تُشتخدم في المعاملات الرسمية. [21] وقيـل: "اللغــة العربيـة الفصـحى هـي لغــة القـر آن الكـريم والتـر اث العربـي جملـة، والتـي تسـتخدم اليـوم فـي

$$
\text { المعاملات الرسمية، وفي تدوين الشعر و النثر والإنتاج الفكري عامة". [22] }
$$




\section{المطلب الخامس: خصائص اللغة الفصحى:}

وتتميز اللغة الفصحى بمميزات عدة، أهمها الآتي:

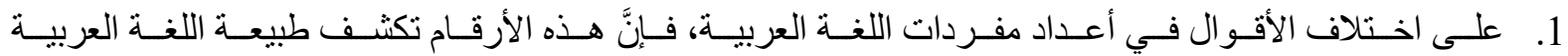

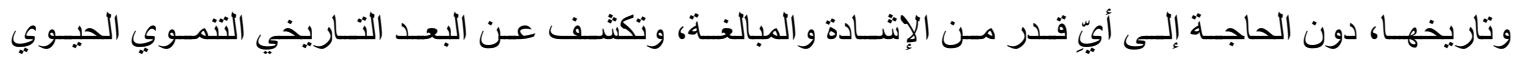

ل لهذه اللغة.

2. اللغـة العربيـة هـي اللغـة القوميـة لمائـة مليـون مـن العـرب، وهـي لغـة الفكر و الثقافــة والعقيـة لألـف مليـون مـن

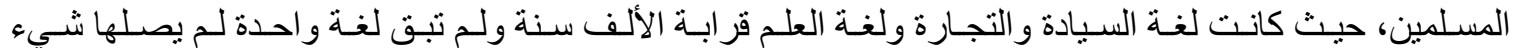

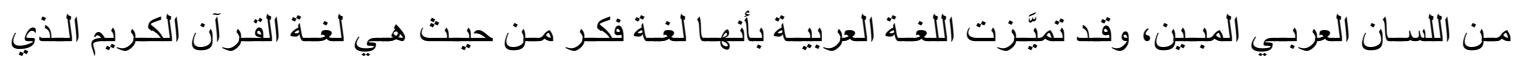
أَلَقى إلى العربية و إلى الفكر الإنساني أضخمَ شحنة من القيم والمبادئ.

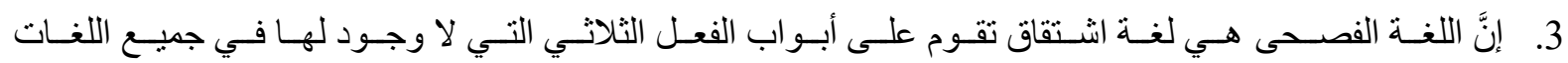
العالميـة؛ ففـي اللغــة العربيـة حـروف لأصــوات لا نوجـد فـي كثيـر مـن اللغــات الأخـرى، مثـل حـرف الغـين

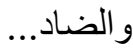

4. تتميز اللغة الفصحى بتنوُ الأساليب و العبار ات، والمعنى الواحد يمكن أن يُؤََّى بطرق مختلفة. 5. مقدرتها على التعبير عن معانٍ ثنانوية لا نعرف الثعوب الغربية كيف تعبِّر عنها.

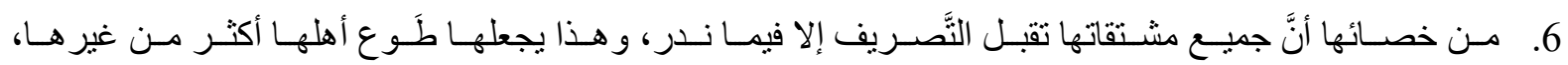
وأوفى بحاجة المتكلمين. [23] وتتميـز بخاصــة إظهـار الأفكـار بطريقـة مـوجزة دون اسـتندراج الســامع إليهــا، كمـا تتميـز بإضـافة الحـوادث إلى الفعل أكثر من إسنادها إلى الفاعل. - الى

\section{- ما يميّز اللغة العربية الفصحى عن غيرها:}

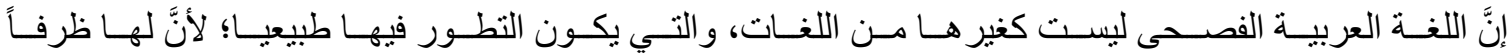

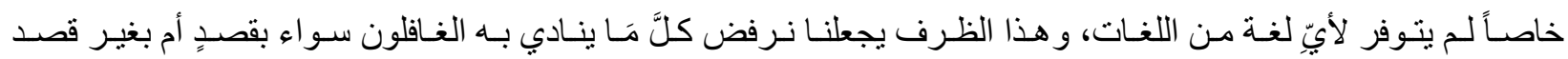
مـن تـرك الحبـل على الغــارب للعربيـة الفصـحى كي تتفاعـل مـع العاميـات كمـا يحـدث مـع كـلِّ اللغـات، صـحيح أنَّ اللغــة 


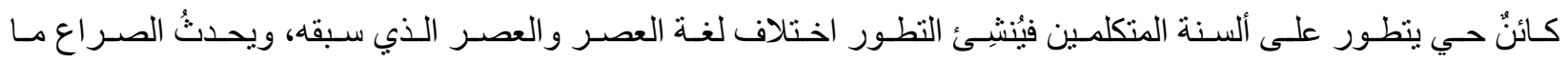

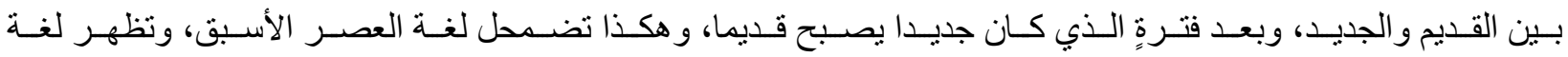
العصر الجديد فهذه سُنَّة كونية، وتاريخ اللغات بشهد بذلك.

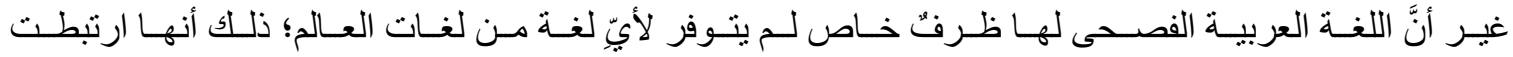

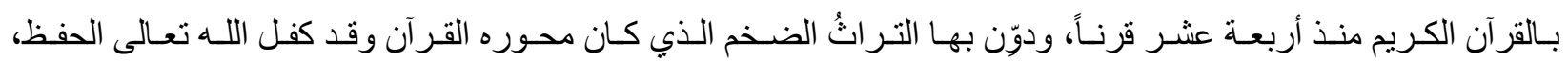

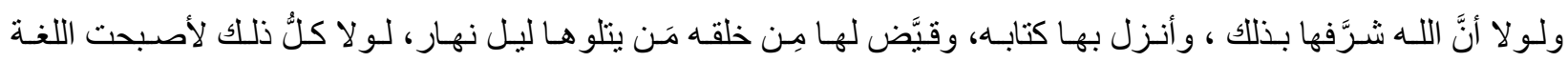
العربية الفصحى لغة أثرية كاللغة اللاتينية و السنسكريتية.

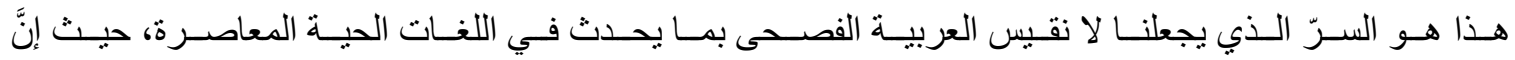

أقصى عمر تلك اللغات لا يتعدى قرنين من الزمن.[24]

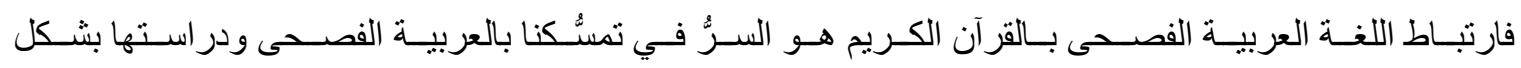

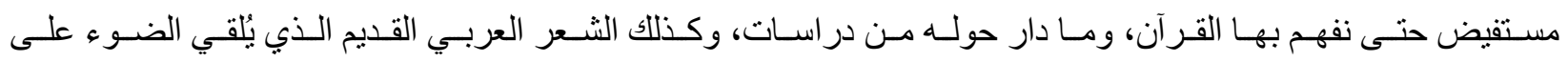
المعاني القرآنية، ويساعد في توضيح بعض معاني القرآن الكريم. [25]

فهذه الفصـحى اسـتمرت حيـة أربعـة عشـر قرنـا، وستسـتمر في حياتهـا إلـى مـا شـاء اللـه، متخـذة مـن القـرآن

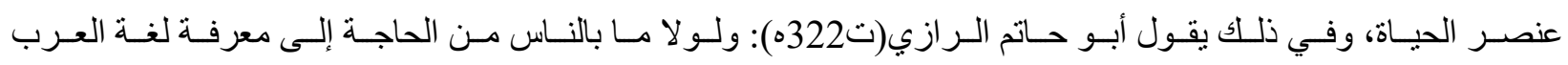

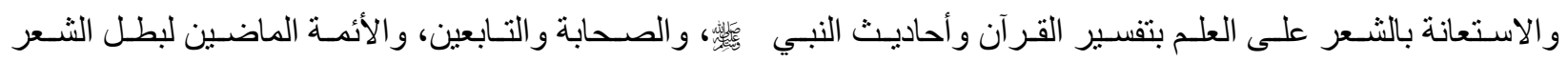
و انقرض ذكر الشعر اء، ولَعَفى الدهر على آثار هم، ونسي الناس أيامهم. [26]

\section{المبحث الثاني: الاعوة إلى العامية}

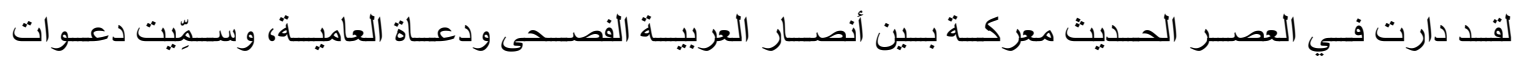

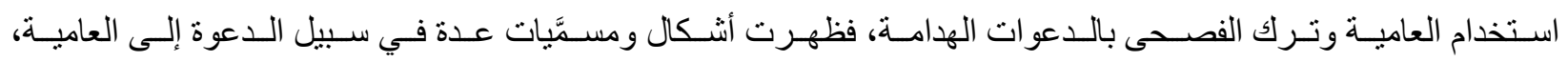

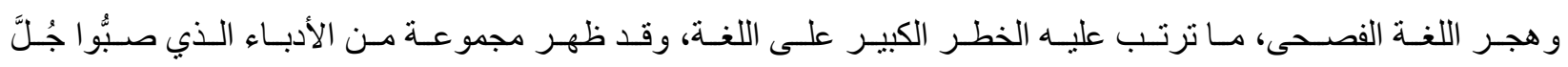

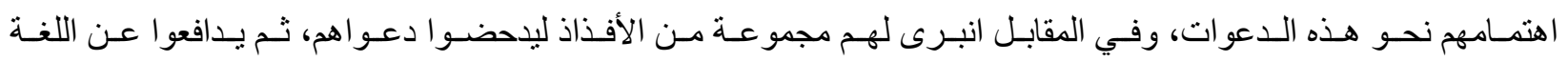
العربية الفصحى، و هذا ما سنتناوله في هذا المبحث. 


\section{أولاً: الدعوة إلى استخدام العامية:}

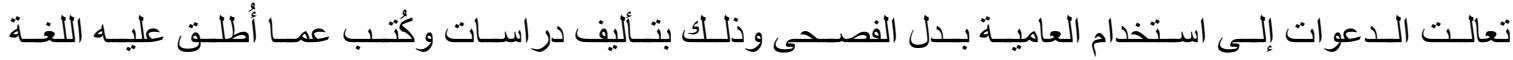
المحكيــة، أو العاميــة المصــرية، ومــن أبـرز الــدعوات دعــوات المستشــرقين (ولــيم ويلكــوكس)1893،(و وســبيتا) الألماني1902، (وويلمر القاضي1910).

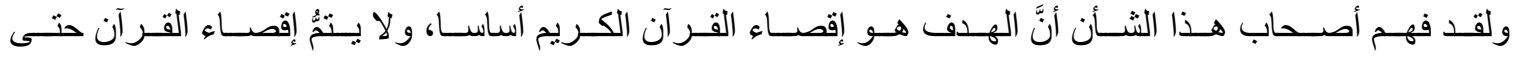
تــوارى اللغـة العربيـة الفصـحى، و (ويلكوكس) أول مـن دعـا إلـى نشـر العاميـة و التـأليف بهـا وقد كـان لـه أسـلوبه المـاكر

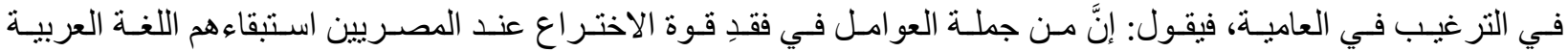
الفصحى، لذلك لا بُدّ من إغفالها واستبدالها بالعامية، اقتداء بالأمم الأخرى، وخاصة الإنجليزية.

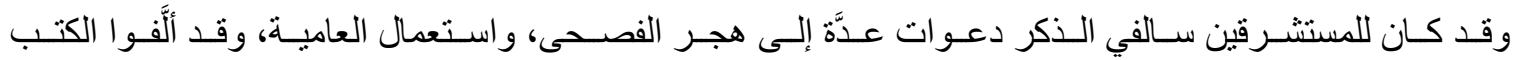

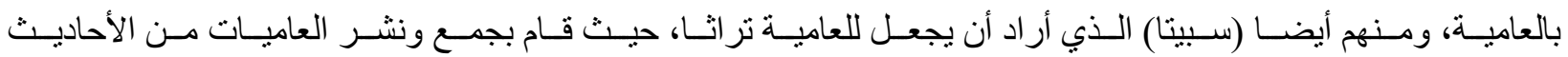
و الفكاهات و الكلمات، وجعلها مقدمة لعمل من جاء بعده. [27]

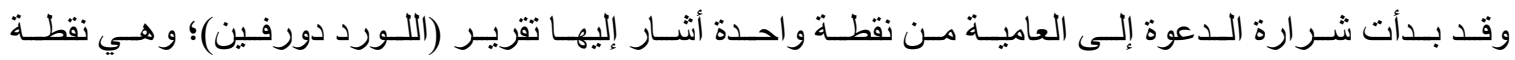

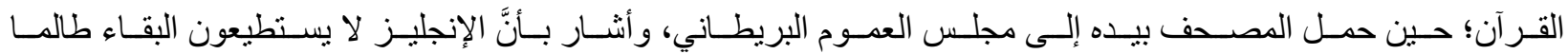
يوجد هذا الكتاب في عقول المسلمين وقلوبهم، في إثارة إلى المصحف الذي بيده.

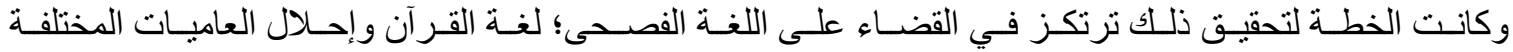

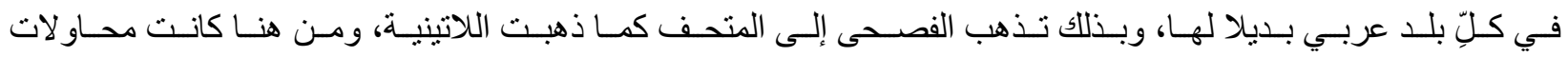

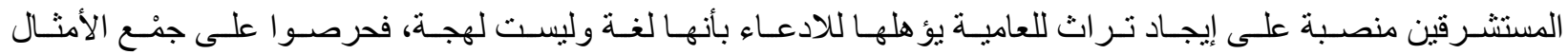
و الأزجال و الكلمات المختلفة.

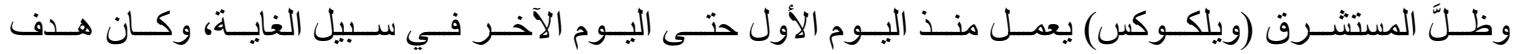
(ويلكـوكس) أن تصـبح العاميـة لغــة خاصـة. ثـم جـاء بعـد ذلــك تلامـذة المستشـرقين مثـل: لطفي السـيد، وقاســم أمسين، وسلامة موسى، ومحمود تيمور ، وغير هم. [28]

وكـان الأمـر الأخطـر هـو أعـداد هـؤلاء النفـر الــنين حملـوا الخصــومة والحـرب للغــة العربيـة الفصـحى تحـت أسـماء بر اقــة زاهيــة، أهمهـا: الإصــلاح، و التمصـير ، وتيسـير النحـو، ودر اســة اللهجــات، حيــث انبـرى طــه حسـين، 


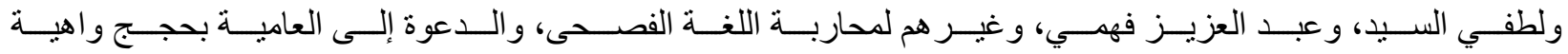

خدَّاعة.[29]

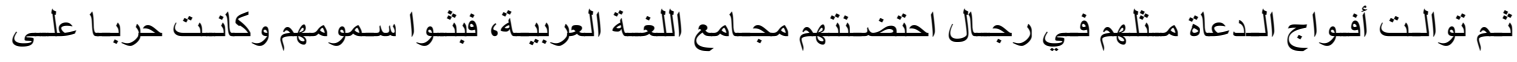
الفصـحى، وجميـع المحساو لات التـي جـرت في سـبيل إعـلاء العاميـة قد بـاءت بالفتـل حيـث عجـزت العاميـة أن تسـتو عب العقل العربي، وأكدت أنَّها لن تسنطيع أن تصل إلى أعماق القلوب. [30] ثانياً: الدعوة إلى استبدال الكتابة واستخدام الحروف اللاتينية:

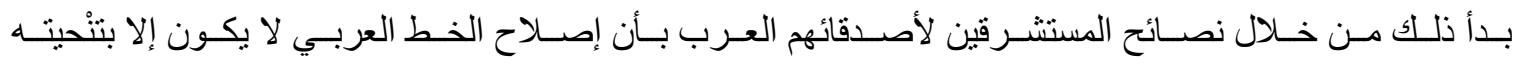

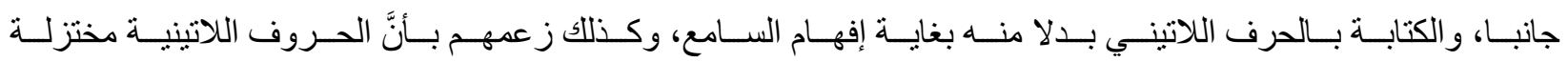

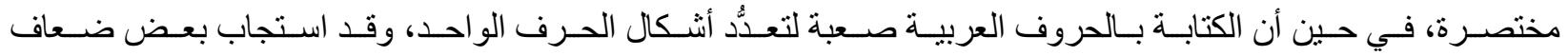
النفوس إلى هذه الدعوة منل عبد العزيز فهمي، وسينمٌ تفصيل هذه الدعوة في المطلب القادم. [31]

\section{ثالثاً: تيسير الكتابة العربية:}

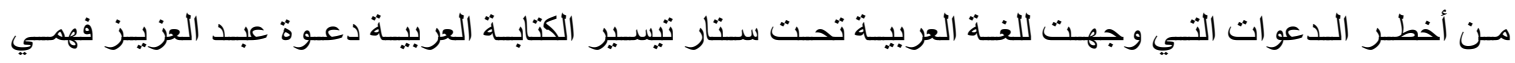

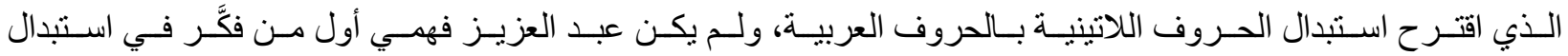
الحـروف اللاتينيـة بـالحروف العربيـة، ولكنَّهـهـ كـان أول مـن اهـتم بـالفكرة اهتمامـا كبيـرا فـي مصـر ، حيـث أجـرى عليهـا

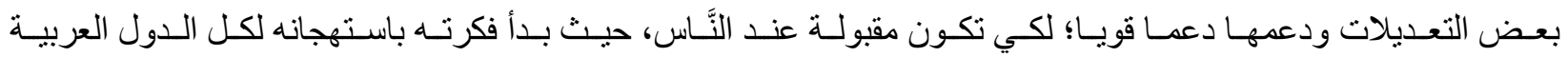
المستقلة سياسـيا التـي لـم تجعل لهـا لغـة خاصـة بهـا، وذكر أنتـا نحن العرب أتعس خلق الله؛ لأنتـا لـم نعـالج التيسبر الذي

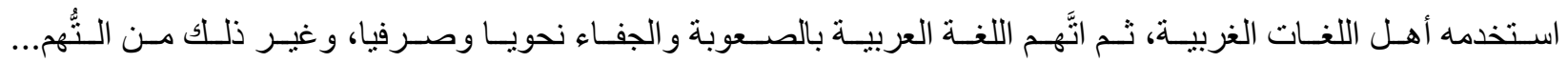
وكذللك دعـوة أنيس فريحـة التـي هـاجم فيهـا اللغــة العربيـة الفصـحى، فدعا إلى هجر هـا وهجر قو اعد اللغــة العربيـة، وكل

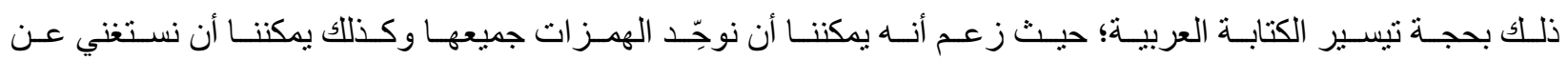
حركات الإعراب؛ لأنَّها تعمل على صعوبة الكتابة العربية. [32] وفي المقابـل ظهـر نمـــ آخـر مـن دعـاة العاميـة مـن محبـي اللغـة العربيـة و الغيـورين عليهـا تحـت سـتار تيسـير

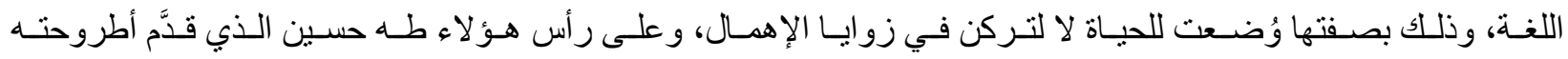
التي تُبين الطريـق للحفـاظ على سـلامة العربيـة، بحيـث تكـون مقربـة مـن العاميـة في يسـرها، بعيدة عنهـا في استهتار ها 
وتملصــها؛ وذلــك بتأهيـل الكـو ادر الإعلاميـة فـي الإذاعـة و التلفزيـون و المسـرح، وتفــادي الأخطــاء السـابقة فـي تيسـير

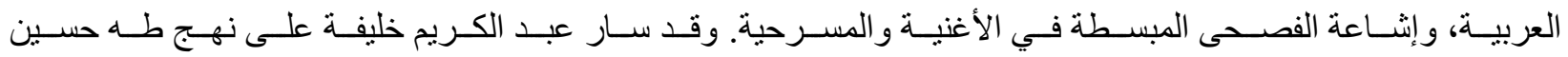

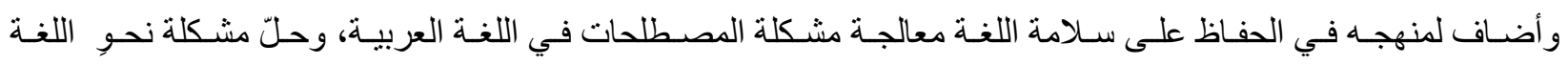
وصرفها، و إنشاء مجلدات تستو عب الفصيح وغير الفصيح. [33] المطلب الثاني: أبرز دعاة العامية والردٌّ عليهم

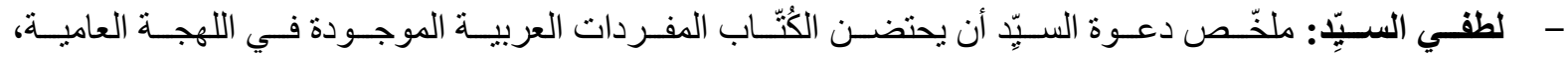

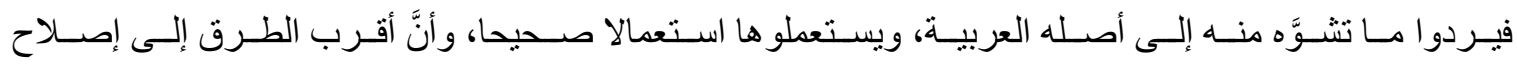
العربيـة باسـتعمال الكلمـات العاميـة، فـإذا اسـتعملناها في الكتابـة اضـطررنا إلى تخليصـهـا مـن الضـعف، وجعلنــا العامة يتابعون الكُتّاب في كتاباتهم.

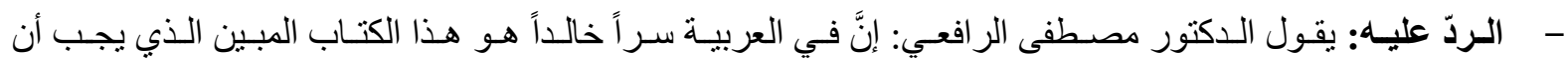

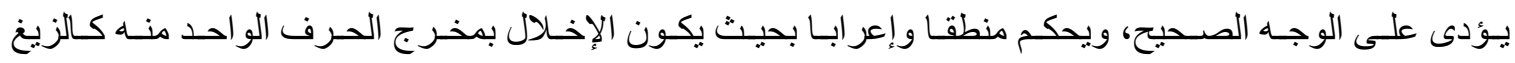

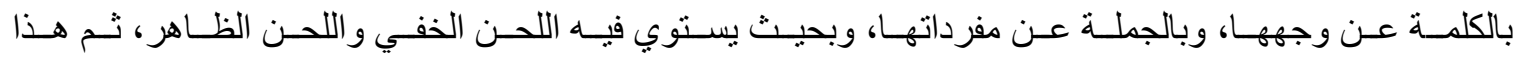
المعنى الإسـلامي (الـدين) المقـام على الفطـرة الإسـلامية، حيـث توزعـت، و أيـن اسـتقرت، فـالأمر أكثر مـن أن

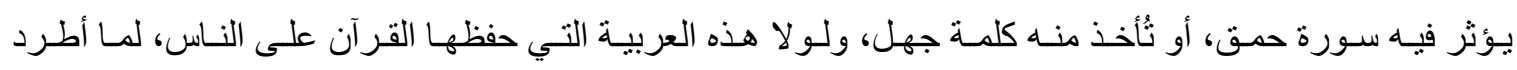
التاريخ الإسلامي، و لا تر اخت به الأيام إلى ما شاء الله، ولما تماسكت هذه الأمة. [34]

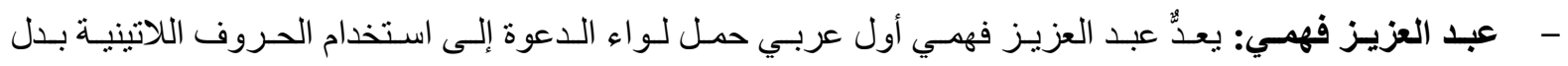
العربيـة، وكـان ذللك على مجمـع اللغـة العربيـة، وقد كانـت فحـوى دعـواه أنـه عـرض مشـرو عا يرمسي إلى اتخـاذ اللاتينيـة لرسـم الكتابـة العربيـة، مسـتندا بــللك إلى قـول (ولمـور ) و(ويلكـوكس) و غيـر هم مـن أنَّ اللغـة كـائن حـي ينمو ويموت مخلِّفا بعده ذرية لغوية.

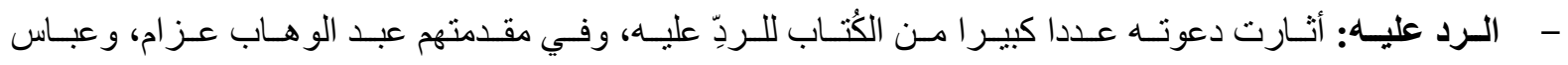

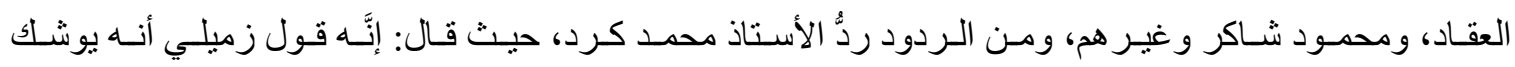
أن تغزونـا اللغــات الأجنيــة فنتـرك لغتتـا، ونسـتعيض عنهـا بلغــة مـن لغـاتهم هـذا خـوف لا محـلَّ لـه؛ لأنَّ العربيـة

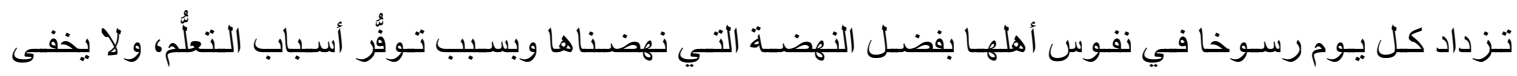




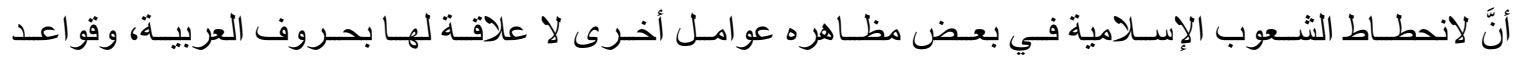
الرسم، وبر هانه ضعيف و لا يصحُّ الاستدلال به.

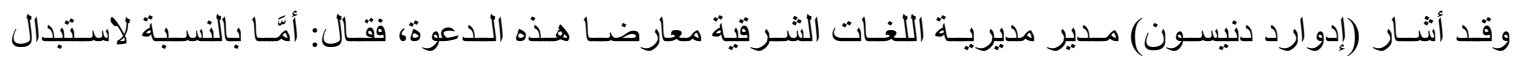
الحـروف العربيـة باللاتينيـة فيََّـاكم وهــا الأمــر ؛ لأنَّ الحـروف العربيـة هـي حـروف لغـة القـرآن، فـإذا مسسـتم بالعربيـة مستم بالقرآن، بل هدمتم صر ح وحدة الإسلام. [35]

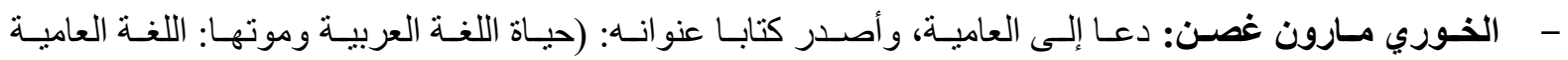

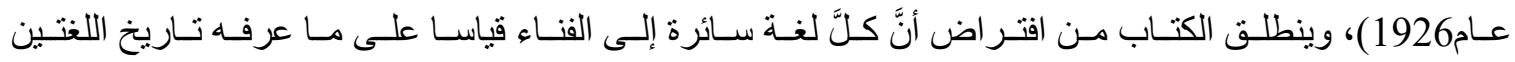

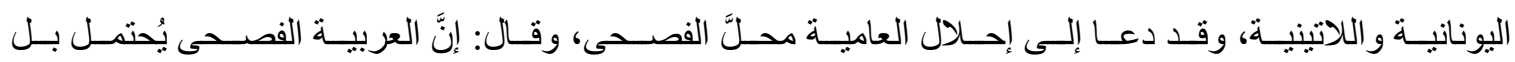
يُرجّح بقاؤهـا فـي القـر آن إلـى منتهـى الأيـام، ولكـن لا ينـتج عـن ذلـك بقاؤهـا فـي الـبلاد العربيـة كمـا هـي إلىى الأزل، وقال: إنَّ الكثير يأنفون من استعمال اللغة الفصحى لنشر أفكار هم، وترويج مقاصدهم. [36]

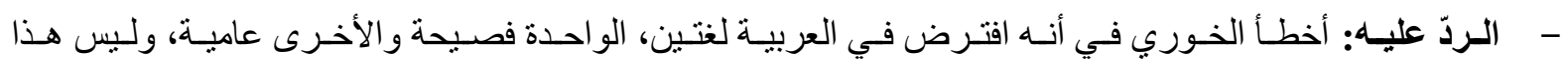

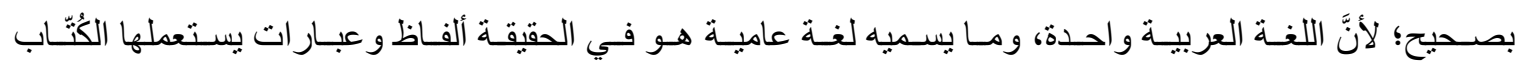
و الأدبـاء، فالعاميـة ممزوجـة بـالأغلاط، وللعاميـة أيضـا لهجـات فـي الحركـات عنـــ الـتكلم بهـا تختلـف بـاختلاف

$$
\text { البلدان شرقاو غربا. }
$$

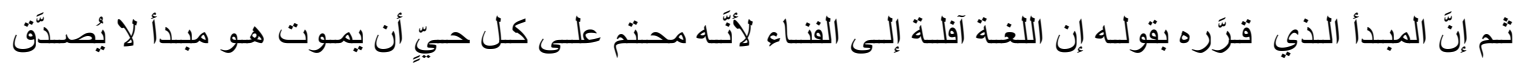

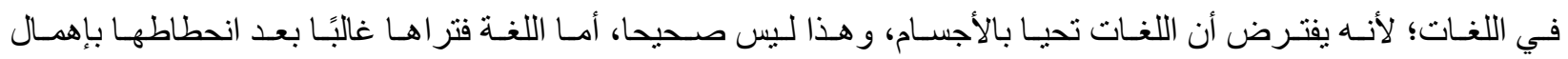
الأدب ومـوت الأدبـاء تـنهض مـن كبوتهـا، وتتـتعش، فاللغـة لا تمـوت كمـا تمـوت الحيوانـات و النباتـات، بـل يمـوت الثـعب الـذي ينطـق بهـا، فـإذا مـا بقي الثـعب العربـي الـذي ينطـق بهـا فإنهـا تحيـا لغتـه، ويتجـدد شـبابها، ولا تـنحط بـل ترتقـي برقي آدابه.

ولنـا مثــال آخـر فـي اللغــة العربيـة، إذ كانــت فـي العصـر الجـاهلي تختلـف معـاني كثيـر مسن ألفاظهـا بـاختلاف

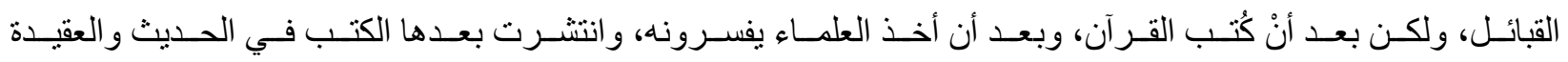

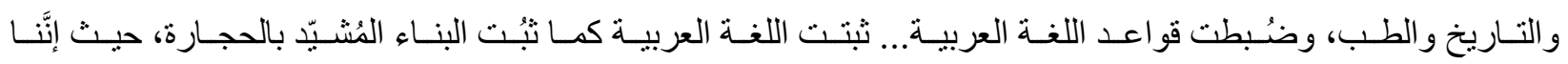




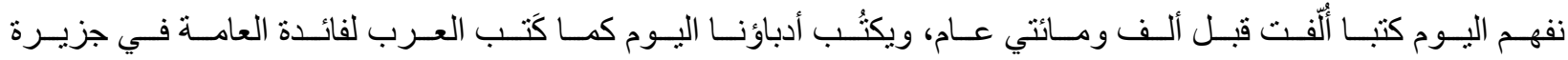
العرب. [37]

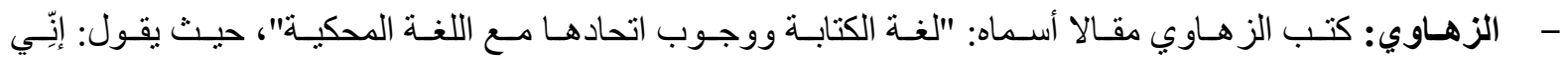

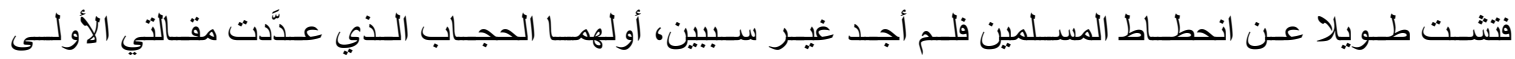

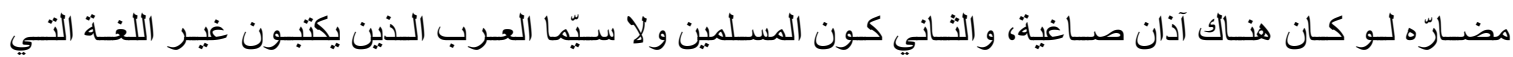

\section{يحكونها.}

وقد صفّق له دعاة التغريب، وأُعجبو ابه فأطلقو ا عليه لقب المُجدّد، والمُحقق و العالِم الكبير.

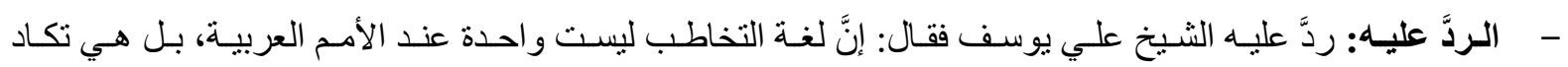

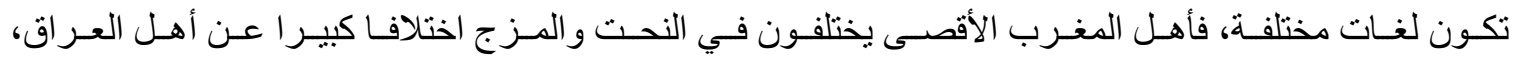

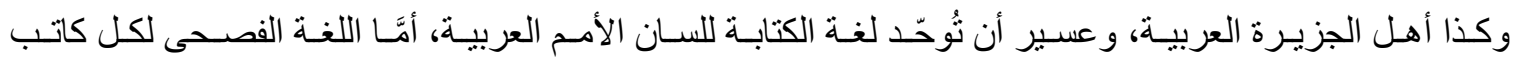
عربي فهي مقروءة مفهومة عند كلّ قر اء العربية، ليس الخاصة فقط، بل الذين ارتفعت عنهم العامية. و هنـاك محساذير أخـرى يجرُ هـا على الأمـم العربيـة اتخـاذ لسـان التخاطب لسـان كتابـة، وذلـك أنَّهـه يجعـل القـرآن بمعزل من القائمين و الكاتبين الذين سيذهب بهم التجدد بعد ذلك كل مذهب. [38] المطلب الثالث: آراء العلماء والأدباء حول مشكلة ازدواجية اللغة

و ومـن خــلال الــدعوات السـابقة للعاميـة، وحصــول مشــكلة الازدو اجيـة بـين اللغــة العربيـة الفصـحى وبـين العاميـة، تباينــت آر اء الكتـاب و العلمـاء فـي هـذه المسـألة وتعـددت الحلـول، و هـذه مجمو عـة مـن الآر اء التـي دارت حولهـا هذه المشكلة:

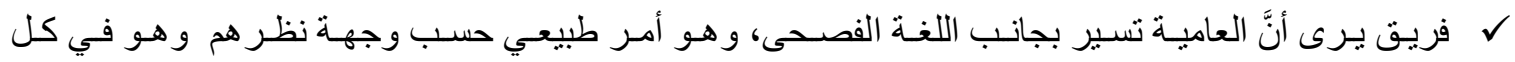

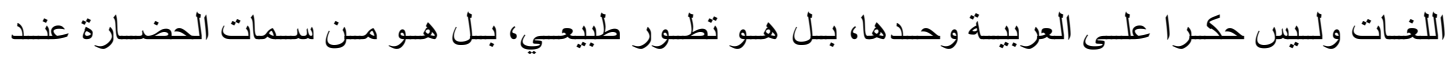
الشعوب.

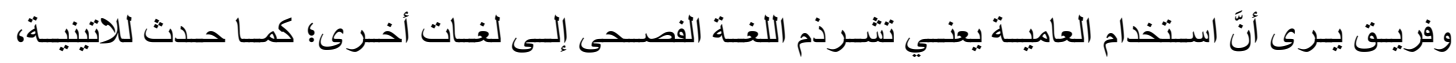
فاعتبروا محاربة العامية أمر لا بُدَّ منه. 


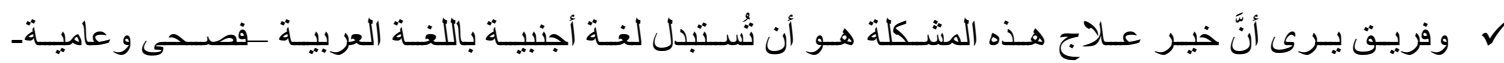
و هـذا القـول سـاقط مـن أصـله، بـل لا يمكـن أن يكـون؛ لأنَّهـ فنـاء للـذات العربيـة بفنـاء لغتهـا، وهـذا الكـلام

$$
\text { ذُكر في الردِّ على عبد العزيز فهمي. }
$$

وفريـق آخـر يـرى أنَّ عـلاج هـذه المشـكلة بـين اللغــة الفصـحى و العاميـة يكـون بنـوع مـن المُلاقـاة بـين اللغــة

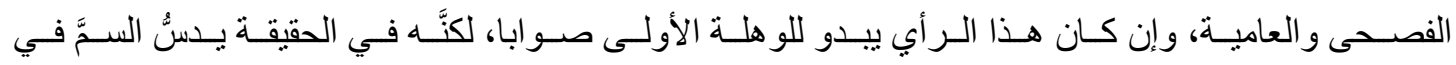

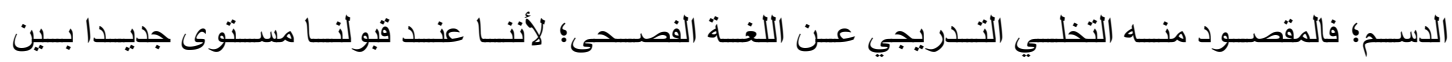

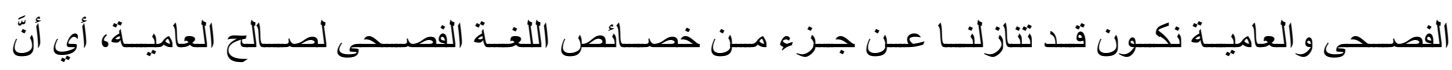
الفصـحى تكـون قـد خسـرت مـن سـماتها بقـدر مـا تنازلنـا عنــه، ولـن يسـتمر هـذا الوضـع اللغـوي طـويلا، فبعد فترة سيظهر ازدواج لغويٌ جديد، يفرض التخلص منه عمل نوع من الملاقاة. [39]

\section{المبحث الرابع: الردَّ على دعاة إحلال العامية محل اللغة الفصحى في اللسان العربي}

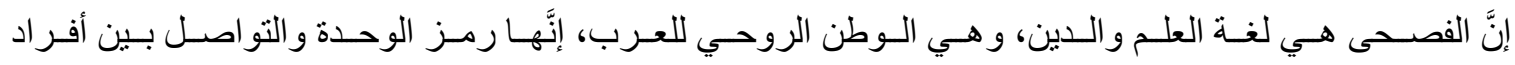

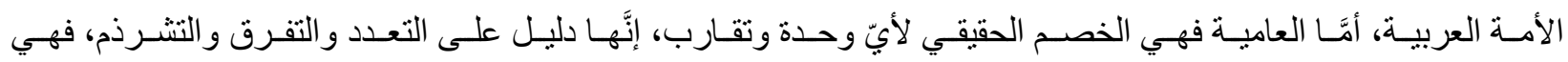
نذير الانفجار لكل منجزات الأمة.

وكذلك فإنَّ نمو العامية لا يكون إلا على حساب الفصحى، فهي تصارع الفصحى من أجل البقاء و السيادة.

و الأمسـة الو اعبـة هـي المنسـمة في طبقاتهـا في بوتقـة واحـدة، وهـي التـي تـدور طبقاتهـا في فلـك واحـد، فـإذا

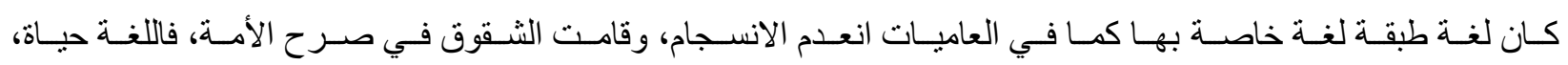

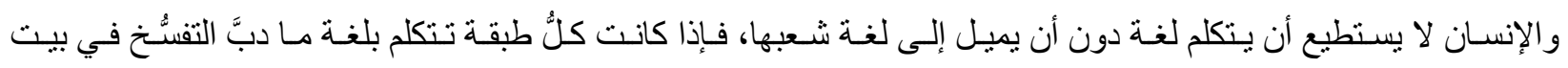

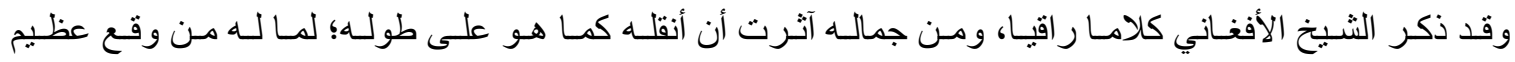

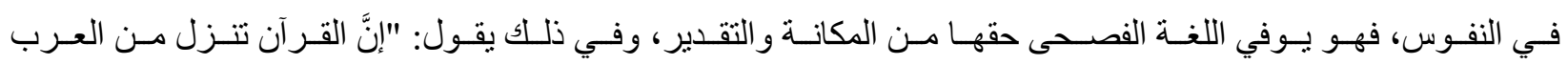

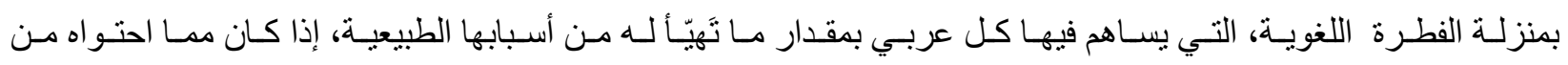

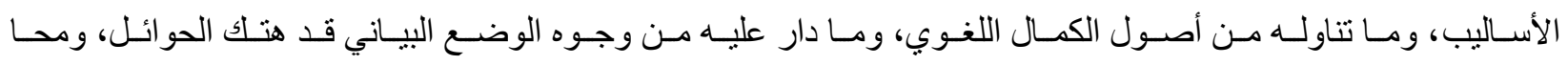




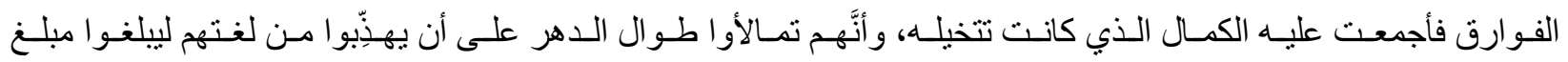
الكمال الوضعي على النحو الذي جاء بـ القرآن.

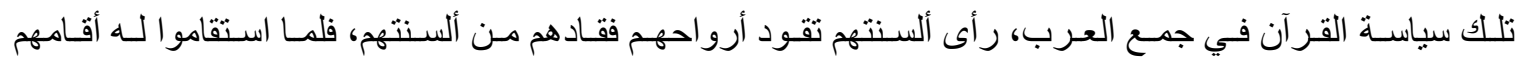
على طريق التاريخ التي مرت فيها الأمم، وطرحت عليه تقائصنها، فكانت غبار ها، و أقامت فضائلها فكانت آثار ها.

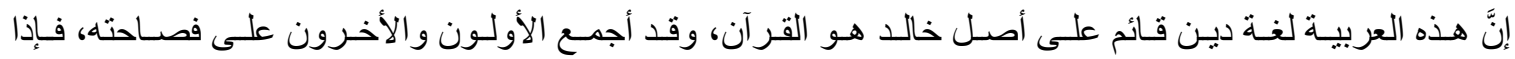
كان المُعز في لغة من اللغات بإجماع علمائها وأدبائها من قديمها فهل يكون الجديد فيها كمالا أم نقصا؟!

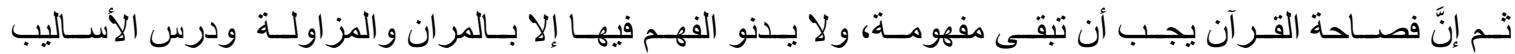
الفصحى، والاعتناء بها و إحكام اللغة، كلُّ هذا يجعل الترخُص في هذه اللغة ضربا من الفساد والجهل". [40] المبحث الثالث: أثر العامية على اللسان العربي

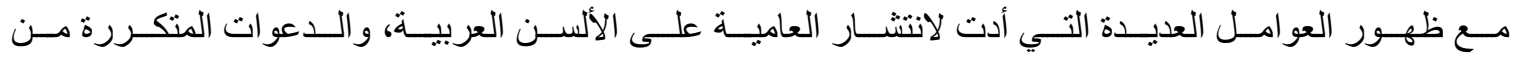
المستشـرقين ومـن طــاو عهم مـن العـرب أصـبحت العاميـة تنتشــر بـل تطغسى علـى لغــة الحـديث اليـومي لــدى العـرب،

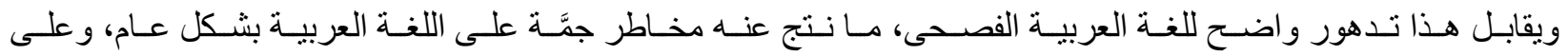
اللسـان العربـي بشـكل خـاص، وفي هـذا المبحـث سـنتناول مخـاطر غلبـة العاميـة على الفصـحى عنـــ العـرب، وكـذلك

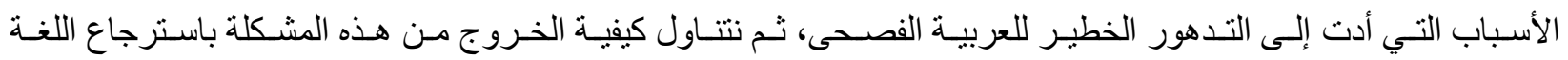
العربية الفصحى لمكانتها، و استعماها في اللسان العربي لدى عامة الناس.

المبحث الأول: أسباب تذهور مستوى الفصى

لـيس مـن شـك في أنَّ مـن أسـباب ظهـور العاميـات وطغيانهـا على اللســان العربـي التـدهور الحقبقي فـي اللغــة العربية الفصحى، ولعل أهم أسباب هذا التدهور الآتي:

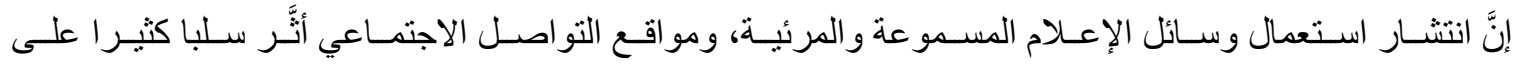
مطالعة الكتاب عند الأجيال العربية، بحيث لم يعد الكتاب خير جليس وأنيس للإنسان العربي المتعلم.

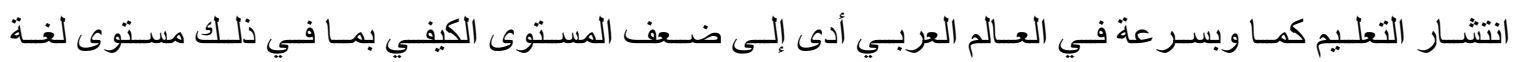
التعليم الرسمية (الفصحى). 


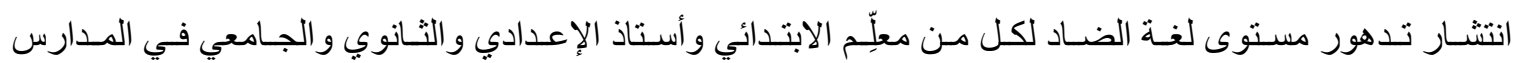

$$
\text { و الجامعات العربية. }
$$

$\checkmark$ ل تفثيّي التأثثرات الثقافية غير العربية بما فيها اللغات الأجنبية، و اللهجات، لا سيَّما في دول الخليج العربي.

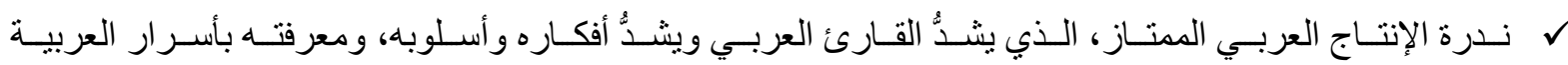

$$
\text { الفصحى نحو ا وصرفا وبلاغة. }
$$

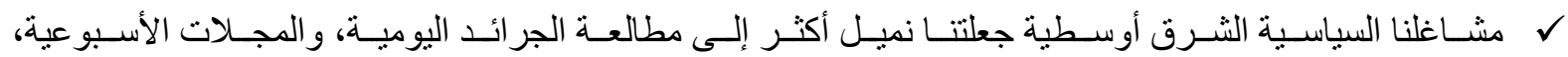

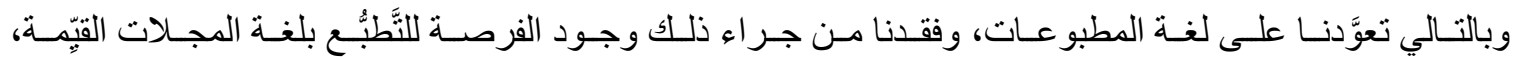
و الكُتب ذات المستوى اللغوي و الفكري المُثري تعبير ا وتصوُر القضايا الحياة المتعددة والمتجددة. [41]

\section{المطلب الثاني: مخاطر العامية على العربية عموما، وعلى اللسان العربي خصوصا: 1. شيوع فكرة العامية في الأمة العربية يؤدي إلى ضعف العامية و الفصحى.}

2. قاعدة التسـامح في اسـتعمال المفردات العاميـة تتسـع في الأجيـال القادمـة إلى درجـة تصـبح الفصـى في كتابهـا

$$
\text { الكريم ضرباً من اللغات الأثرية. }
$$

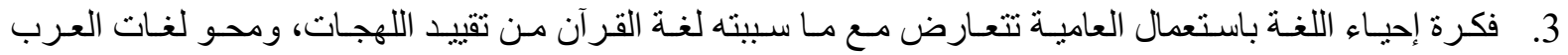

جميعها على فصاحتها، وردّها إلى لغة واحدة. [42]

4. اتخاذ العامية للحديث و الكتابة ينتج التفاهم مؤقتا في بيئة محدودة، وزمان محدد.

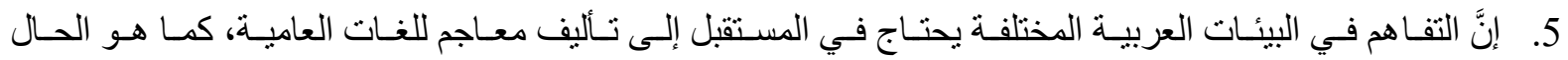

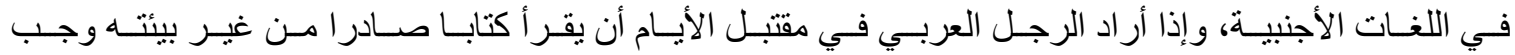
عليه الاستعانة بالمعجم لترجمة اللغة العامية.

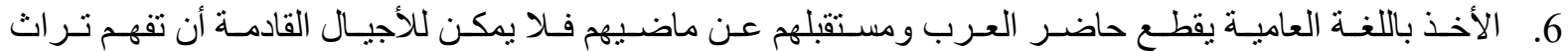

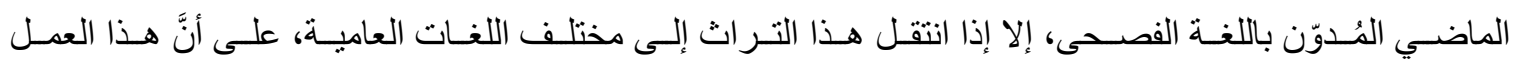
يحتــاج إلـى وقـت كبيـر وجهـود عديـدة، لا قِبـل لأحسٍِ بهـا، ولا سـيّما إذا علمنــا أنَّ التـراث العربـي ضـخم جـدا، ولا ننسى أن النقل المُتكرر للنصوص يُشِوِه روح النصوص ويبعدها بالتدرج عن أصلها الفصيح. 


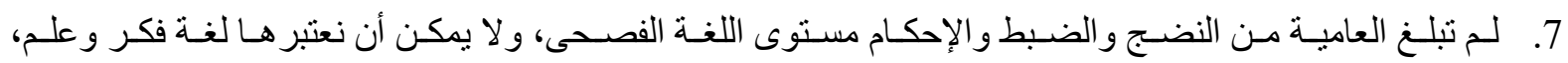

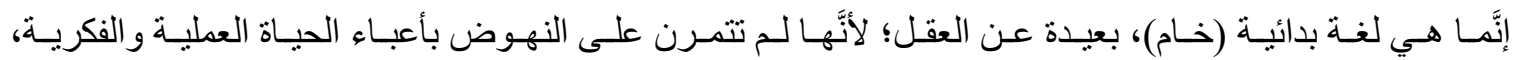

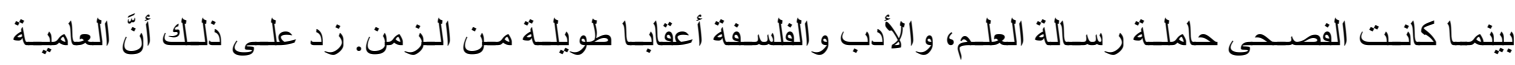

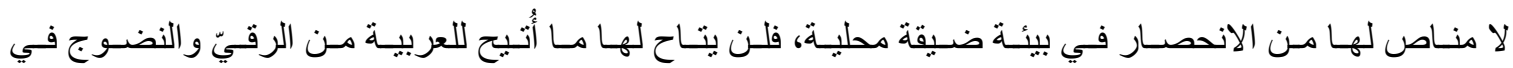
شيو عها.

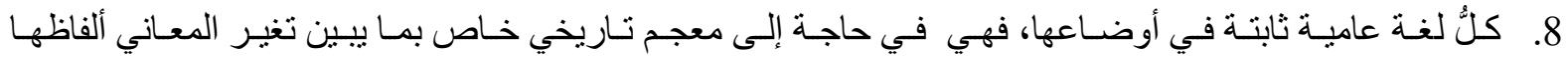

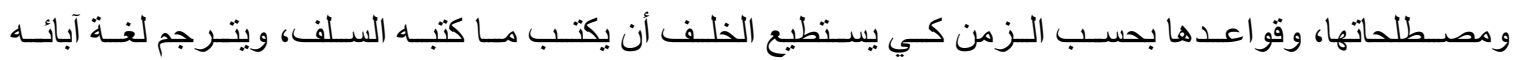

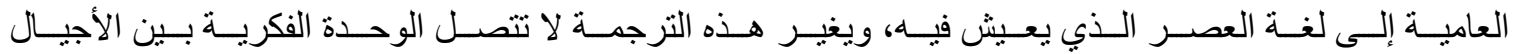
المتعاقبة. [43]

9. انتشــار العاميـة يعمـل على خنـق الفصـحى ويقف حـائلا دون انتشـار ها خـارج نطـاق الـوطن العربسي، فهي تمنـع

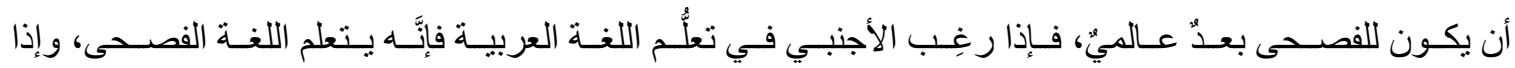
حـادَث أبنـاء العربيـة اسـتخدم الفصـحى التـي قد يصـعُب فهمهـا على محسور النـاطقين بالعربيـة، فـلا يسـتطيعون

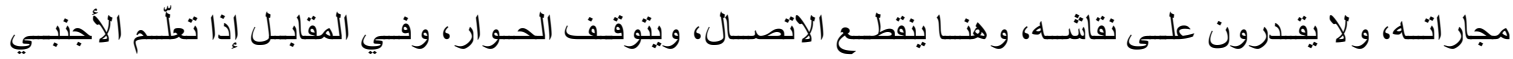
اللغــة مشـافهة في إحـدى البيئـات العربيـة فإنَّهـ يتعلم عاميـة تلـك المنطقة، فـإذا مـا انتقل إلى بيئـة عربيـة أخـرى انغلق عليه فهم عاميتها، وصعب على أهل تلك المنطقة فهم العامية التي يجسدها هو. [44]

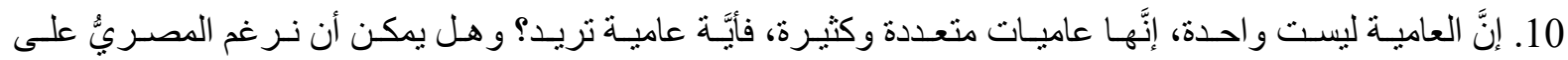
اصـطناع عاميـة العر اقي، أو العر اقـي على اصــطناع لغـة المصـري؟ فالــدعوة إلـى العاميـة دعـوة إلـى التحيُّز و التحلِِ، وفوق ذلك انفلات من الروابط الجامعة بين البشر.

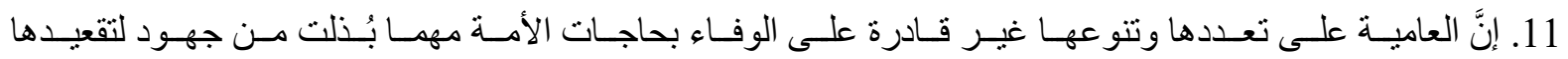

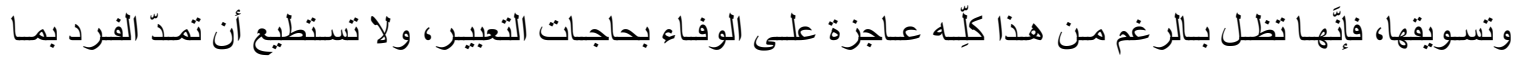
يحتاجه من ألفاظ و أساليب.

12. إنَّ اللغــة العاميــة لا تناســب اللغــة الإعلاميــة، و لا تفــي بحاجاتهــا، فوسـائل الإعـلام علـى اختلافهـا وتتوعهــا تصطنع لغة أقرب إلى الفصحى، لذا اقتضى تنحية العامية و إقصاءها وتجاوز ها. 


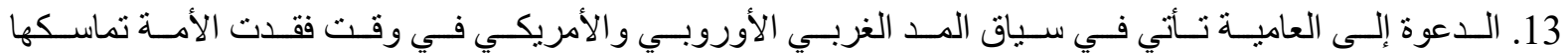

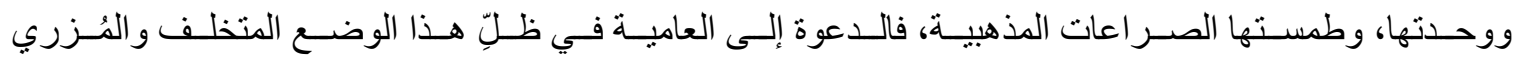
يحمل بين ثناياه بذور التوجُس والريبة، فماذا يبقى للأمة كي نخسر بعد هذا الخسران المبين. [45]

\section{المطلب الثالث: كيفية الحفاظ على اللسان العربي من خطر العامية}

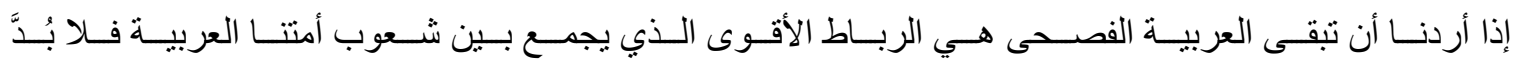

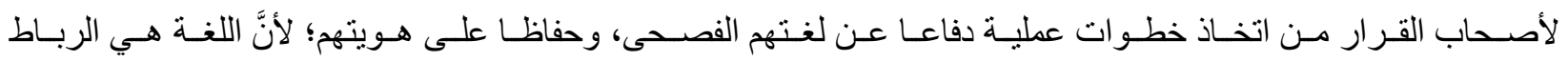

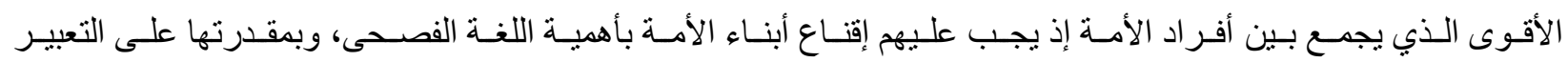
عن كل منطلبات العصر، وقدرتها على استيعاب مصطلحات العلوم والثقافة. [46]

\section{وهذه بعض المقترحات العملية للحفاظ على اللسان العربي:}

1. إعـادة النظـر فـي المنــاهج التربويـة و التعليميـة المتداولـة بحيـث تخلـص هـذه المنــاهج لتحقيـق القـراءة و الكتابـة

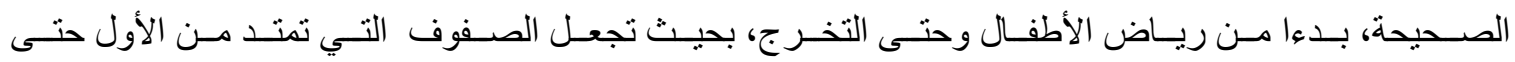

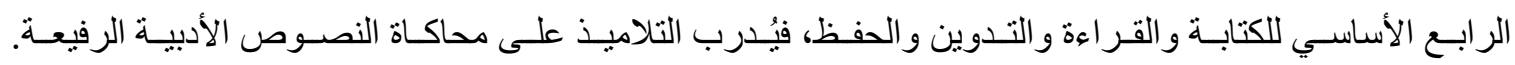

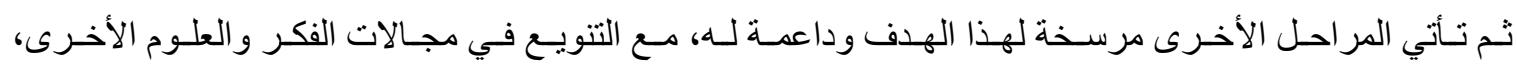

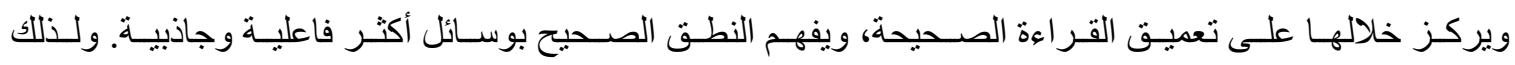

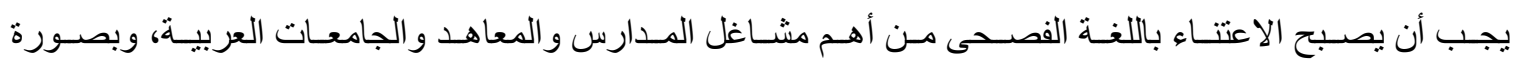
أثـــل ينبغـي إدمـاج مبـدأ الإلمـام الضـروري باللغــة العربيـة فـي السياســات الثقافيـة للمجتمعـات العربيـة بحيــث يصـبح الأمـن اللغـوي ـالـتمكن مـن معرفـة كافيـة بالفصــى كتابـة وقـر اءة وحـديثا- جـز عا لا يتجـز أ مـن الأمـن الثقافي في كل مجتمعات الأمة العربية. [47]

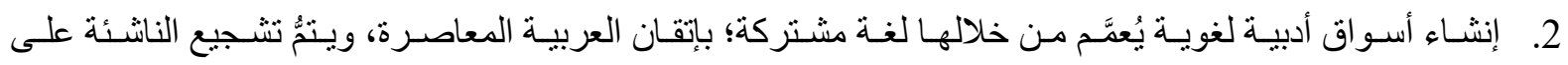

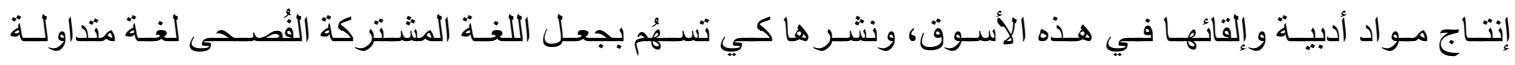

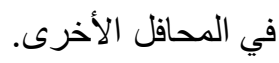




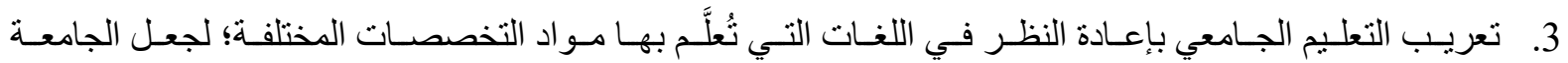

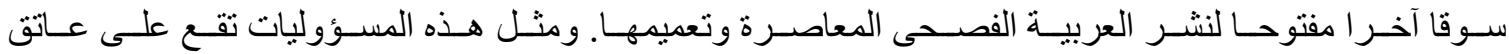
الجامعات ومؤسسات المجتمع المدني من جهة ومؤسسات الدولة من جهة أخرى.

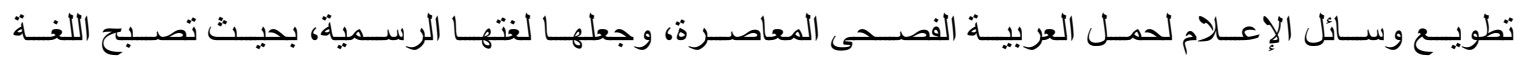

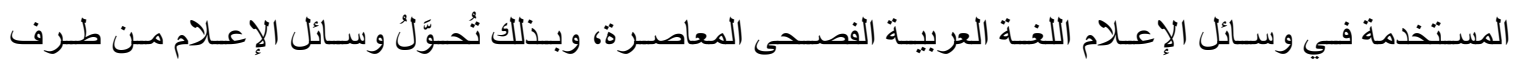
في المشكلة إلى طرف مؤثر في الحل. [48]

5. إعـادة التقــة بالفصـحى لأنَّهـا تعبـرُ عـن سـيادة الأمسـة الناطقـة بهـا، فهـي لغــة رسـمية في محافـل الأمـم المتحـدة، ووكالاتها المتخصصة.

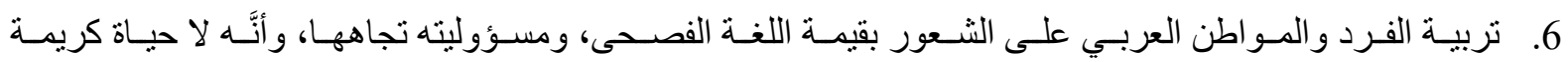
له إلا بها، و لا يمكن أن يحيا في لغة أخرى أو بها، فهي و عاء شخصيته وحضارته وتاريخه.

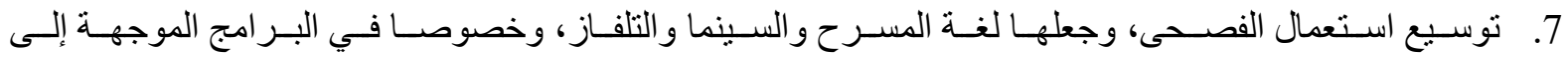
الأطفـال الصـغار، الـذين يعتمدون إلـى حدٍ معين إلى السـماع في تكـوين حافظـاتهم اللغويـة، لـذا مـن الضـروري أن يلتفــت القـائمون علـى أمـر هـذه القــوات إلـى الوسـيلة الفاعلـة فـي توصـيل رسـالتهم إلـى النـاطقين باللغــة العربية، والفصحى خير و عاء لذلك. [49]

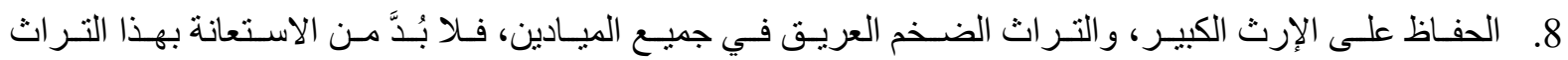
في سبيل ترسيخ اللغة العربية الفصحى في أذهان الناطقين بها. [50] 1. السبب الرئيس في نثأة العامية هو خروج اللغة العربية من موطنها الأصلي، واحتكاكها باللغات الأخرى. 2. للاستعمار الأوروبي دورٌ بارزٌ في نشر العاميات وفرض اللغات على العرب، لأهداف معلنة أو مخفية.

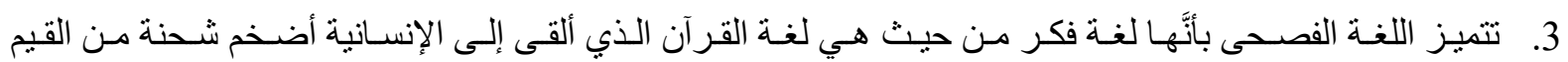
و المبادئ. 


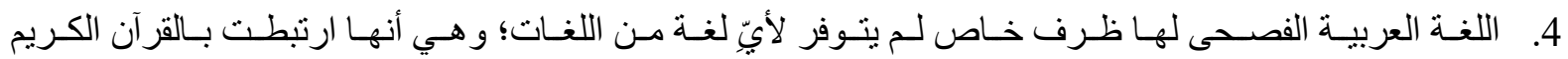
قريبا من خمسة عشر قرنا، وتكفّل الله بحفظها، وقتيَّ لها من يتكلم بها آناء الليل و أطر اف النهار.

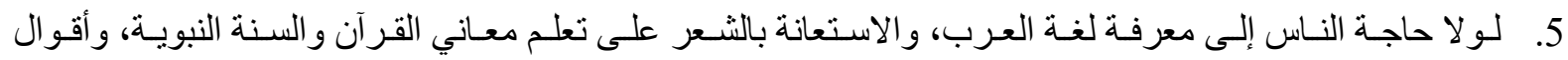
الصحابة و التابعين لبطل الثعر واندثر ذكر الشعر اء.

6. معظم دعاة العامية العرب حاولوا أن يسقطو ا تجربة اللغات الأجنبية على اللغة العربية .

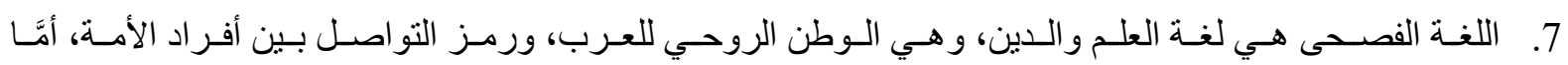

$$
\text { العامية فهي الخصم الحقيقي لأيّ تقارب بين العرب. }
$$

8. مو اقـع التو اصـل الاجتمــاعي، ووسـائل الإعـلام أتثرت سـلبيا على اللغــة الفصـحى بحيـث نشـرت العاميـات بـين

$$
\text { المستمعين، وكذلك لم يعد الكتاب خير جليس وأنيس للإنسان. }
$$

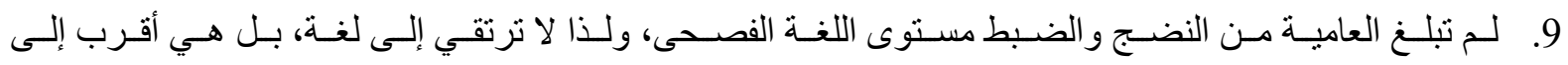

$$
\text { 10. - اللعامية على تعددها و انتثاها الو اسع غير قادرة على الوفاء بحاجات الأمة العربية. }
$$

1. عمل بر امج توعوية ذات بعد إستراتيجي لإقناع المواطن بأهمية الاعتماد على الفصحى ونبذ العامية.

2. إعـادة النظـر فـي المقـررات المدرسـية و الجامعيـة، بإضــافة مـو اد تدريبـة ووسـائل متتو عـة لترسـيخ الفصـحى على ألسنة الطلاب.

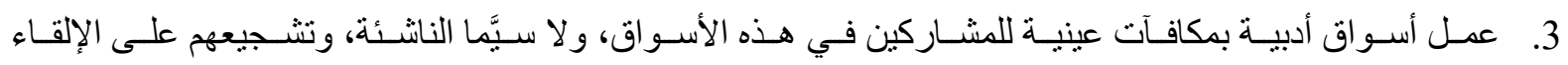

$$
\text { والتحدث بالفصحى. }
$$

4. تفريغ الطلاب في المراحل الأساسية الأولى لتعلم الفصحى كتابة وقر اهة وحديثا.

5. تهيئة المدرسين لغويا في جميع التخصصات، و اشتر اط التكلم بالفصحى كثرط لمز اولة المهنة.

6. إنشاء صلالونات أدبية مسائية تتبع لخطة استر اتيجية ممنهجة محصلتها إثراء المحصلة اللغوية لاى الناس. 


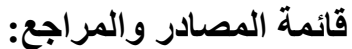

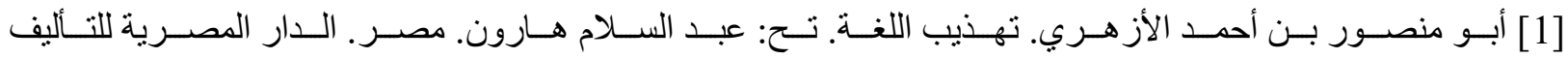

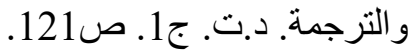

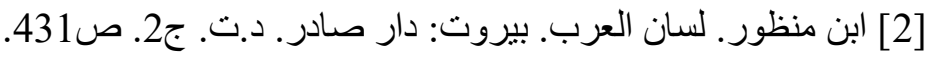

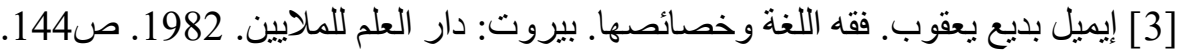

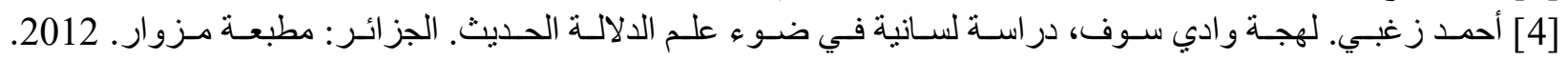
ص19. - n (19)

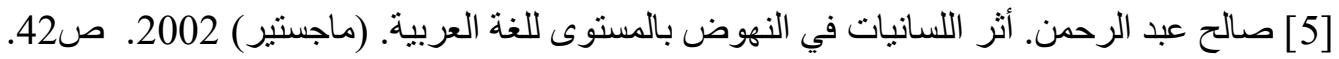

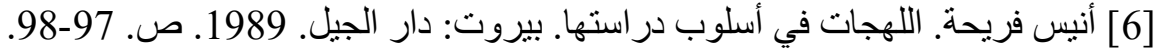

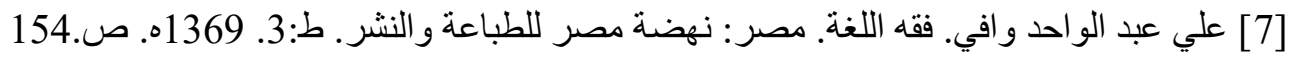

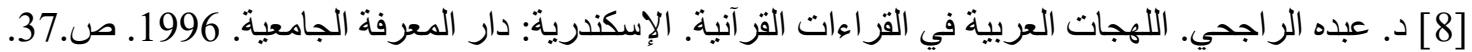

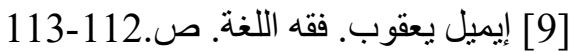

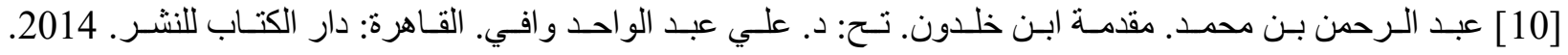
ص.559. (10)

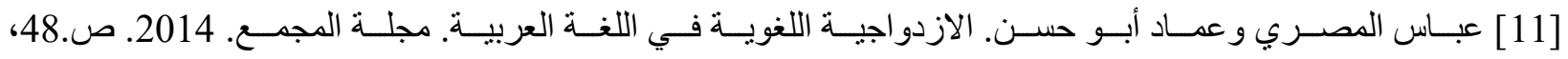

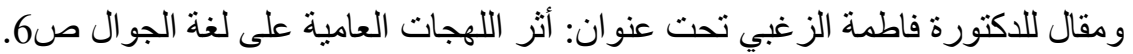

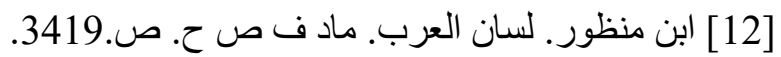

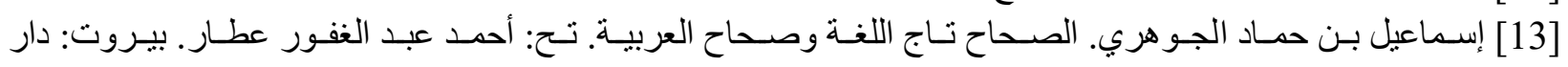

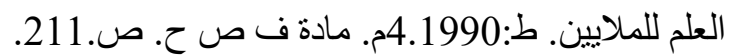

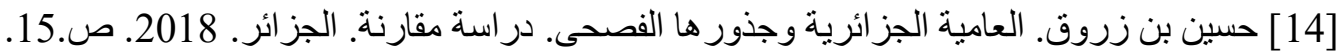

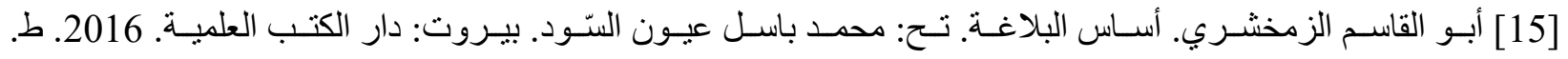

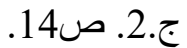

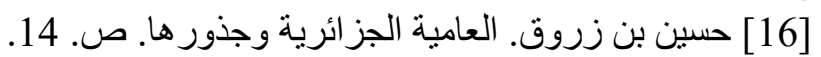

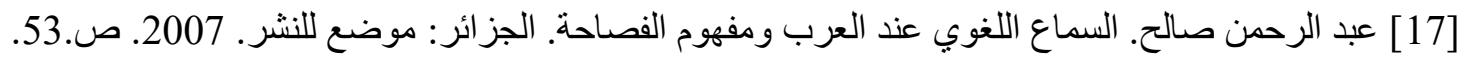

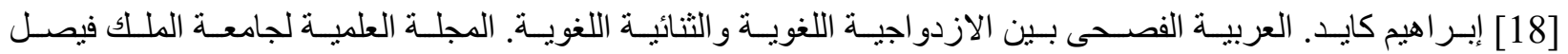
بن فهد. العدد 2002/1.

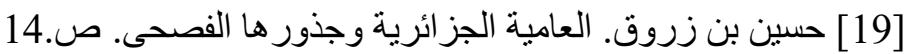

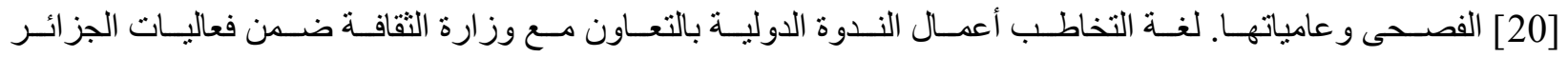
عاصمة الثقافة العربية.

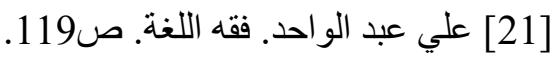

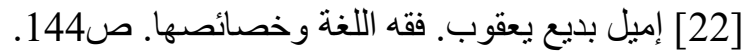

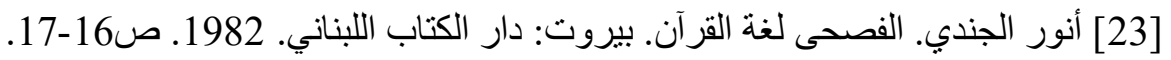

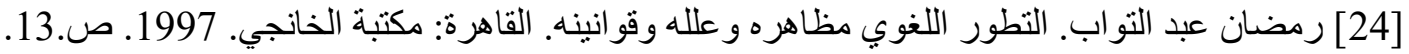
[25] ابن الأنباري. إيضاح الوقف و الابتداء. تحقيق: محي الدين الدين رمضان. [26] أبو حاتم الرازي. الزينة في الكلمات. تحقيق: حسين الهمذاني. القاهرة 1957، 116/1.

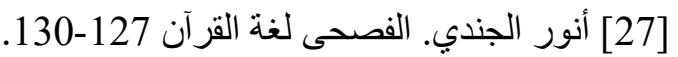

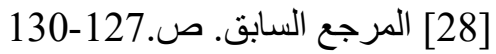
[29] أحمد الخطاب عمر. يسروا النحو للمعربين. الكويت: مجلة العربي. العدد 229 ـ 1983.

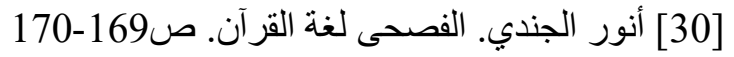

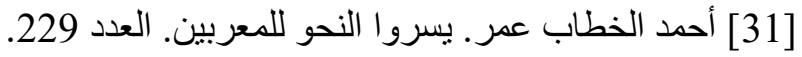

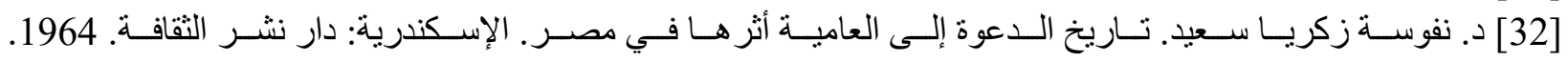




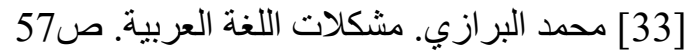

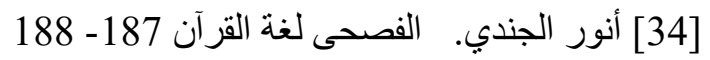

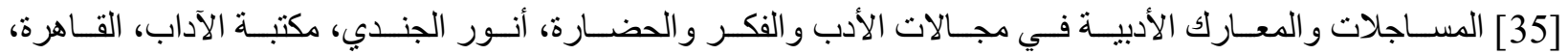

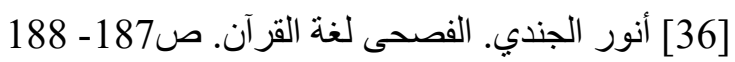

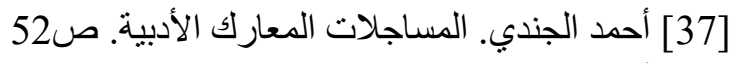

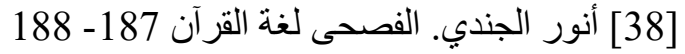

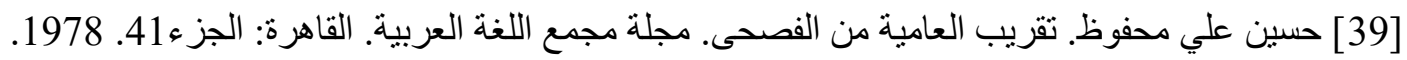

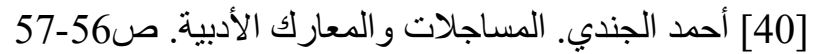

[41] حافظ علوي، و عبد الكريم عزي. اللسان العربي و إثكالية التلقي. مركز در اسات الوحدة العربية. ص20.

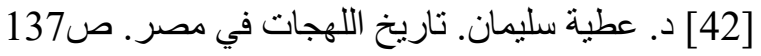

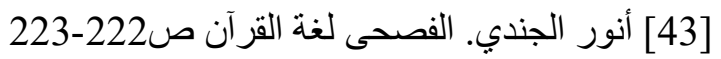

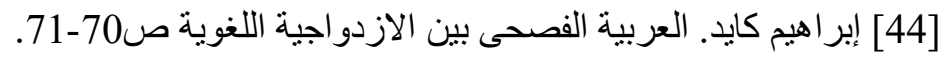

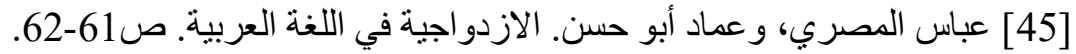

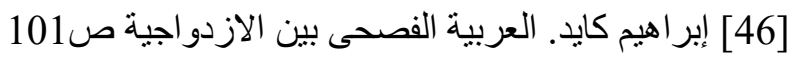

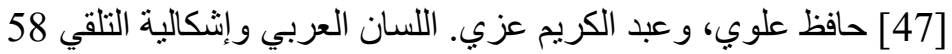

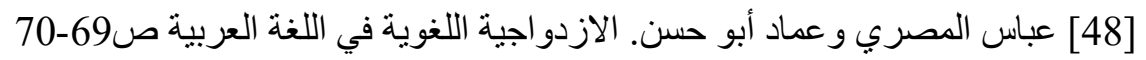

[49] محمد موسى جبارة. اللغة العربية في العصر الحاضر . مشكلات وحلول، صحئ صحيفة الجزيرة.

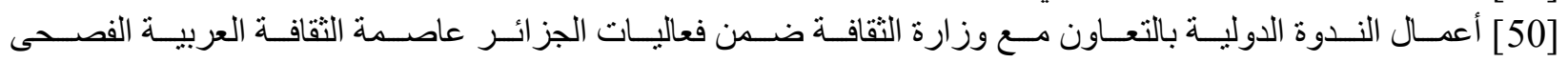

و عامياتها. ص67. 